\title{
The Domestic Status of the Human Rights Clauses of the United Nations Charter
}

\author{
Bernhard Schlüter*
}

I

\section{INTRODUCTION}

This study explores the relationship of the human rights provisions of the United Nations Charter ${ }^{1}$ to the domestic legal orders of the member states. As such, it considers whether these provisions as a whole, or any of them alone, have any legal effect upon domestic judicial and

* Dr. Jur., University of Heidelberg, 1972; LL.M., University of California, Berkeley, 1972. Mr. Schlüter is presently working in the secretariat of the European Commission of Human Rights of the European Council, Strasbourg, France.

1. The Charter of the United Nations contains several explicit references to human rights:

The preamble expresses the determination of the "peoples of the United Nations ... to reaffirm faith in fundamental human rights, in the dignity and worth of the human person, in the equal rights of men and women."

Art. 1, para. 3 defines as one of the purposes of the Orgauization "[t]o achieve international cooperation .... in promoting and encouraging respect for human rights and for fundamental freedonis for all without distinction as to race, sex, language, or religion."

Art. 13, para. 1(b) authorizes the General Assembly to "initiate studies and make recommendations for the purpose of . . . assisting in the realization of human rights and fundamental freedoms for all without distinction as to race, sex, language, or religion."

In Ch. IX, "International Economic and Social Cooperation," art. 55(c) establishes as a purpose of the Umited Nations the promotion of "universal respect for, and observance of, human rights and fundamental freedoms for all without distinction as to race, sex, langnage, or religion."

In art. 56, a provision of particular importance in the prcsent study, "All Members pledge themselves to take joint and separate action in cooperation with the Organization for the achievement of the purposes set forth in Article 55."

Art. 62, para. 2 authorizes the Economic and Social Council (ECOSOC) to "make recommendations for the purpose of promoting respect for, and observance of, human rights and fundamental freedoms for all;" art. 68 empowers the ECOSOC to set up a commission "for the promotion of liuman rights."

Art. 76(c) defines as a basic objcctive of the trusteeship system "to encourago respect for lruman rights and for fundamental freedoms for all without distinction as to race, sex, language, or religion."

For other references to human rights, primarily implicit ones, see, e.g., U.N. ChARTER, preamble; art. 1, para. 1; art. 2, para. 3; art. 14; art. 62, para. 1; art. 68, 73(a), and 76(d). 
administrative processes. What their legal impact on governmental behavior toward individuals may be, whether they confer any rights upon individuals that can be invoked in national courts, and whether they can be applied by courts without further legislative implementation are all discussed.

Many of the problems raised involve the concept of self-executing treaties, a doctrinal notion of high complexity. ${ }^{2}$ Although there is no general agreement on the exact definition of the term "self-executing,"3 I will use it to mean "applicable by, or binding upon, national courts without legislative implementation." Such direct application can take different forms, each of which may liave to meet different requirements. ${ }^{4}$ Among these various modes of application, the two most important are: (1) as a standard articulating traditional civil rights or fundamental freedoms ( $A$ bwehrrechte) against which the legahity of governmental behavior is to be measured, and (2) as a legal basis for certain social and economic rights as claims against the government. ${ }^{5}$ This inquiry is not concerned, however, with the meta-legal significance of the human rights clauses. Although there are many indications that the clauses have had a considerable pohtical and moral influence upon the development of a number of national legal orders, ${ }^{6}$ this study only traces the impact through the legal mechamisms of application.

The domestic legal impact of the Charter is of particular importance not only because it can be assessed in relatively exact terms, but also because other international and national efforts to promote human rights have failed to produce satisfactory results. ${ }^{7}$ For example, the ratification of the Umited Nations Covenants on Civil and Political

2. See generally A. BLECKMANN, BegRIFF UND KRITERIEN DER INNERSTAATlCHEN ANWENDBARREIT VÖLKERRECHTLICHER VERTRÄGE (1970); A. KolleR, Die UNMTTTELBARE ANWENDBARKEIT VÖLKERRECHTLICHER VERTRÄGE UND DES EWG-VERTRAGES IM INNERSTAATLICHEN BEREICH (1971); Evans, Self-Executing Treaties in the United States of America, 30 BrIT. Y.B. INT'L L. 178 (1953). See also L. WILdHABER, TREATYMaking Power and Constitution ch. 7 (1971).

3. For definitions see, e.g., Colloque européen: Le problème des dispositions directement applicables des traités internationaux et son application aux traités instituant les Communautés Européenes, DeuXtème Colloque DE DROIT EUROpÉEN, LA HAYE 24-26 octobre 1963 (1966); A. BleckMANN, supra note 2, at 50-55; A. Koller, supra note 2, at 68; Evans, Some Aspects of the Problem of Self-Executing Treaties, 1951 A.S.I.L. PROCEEDINGS 66, 68, 73-74.

4. Cf. Wright, National Courts and Human Rights-the Fujii Case, 45 Am. J. INT'L L. 62, 77-78 (1951).

5. See text accompanying notes $236-40$ infra.

6. For details see Measures Taken Within the U.N. in the Field of Human Rights, U.N. Doc. A/C. 32/5 (1957); Schwelb, The Influence of the Universal Declaration of Human Rights on International and National Law, 1959 A.S.I.L. PRoCEEDINGs 217. See also the national reports in U.N.Y.B. HuMAN Rights.

7. Cf. Wright, supra note 4 , at 80 . 
Rights and on Economic, Social and Cultural Rights ${ }^{8}$ proceeds so slowly that there is little hope that these covenants will become effective in the near future. In addition, the development of international customary law, though accelerated by the International Bill of Human Rights, may not automatically influence the domestic law of the various nations. ${ }^{9}$ Moreover, the existing international systems of human rights protection, in particular the European Convention on Human Rights, are limited in their geographical and substantive law coverage. ${ }^{10}$ Possibly most important, the human rights guarantees embodied in the constitutional law of many states are often too limited.

This situation invites one to search for alternative techniques to promote the protection of human rights. ${ }^{11}$ Domestic application of the luman rights provisions of the United Nations Charter seems particularly promising for two reasons: First, the Charter is almost universally accepted; and second, its impact nay not depend on further legislative implementation by the meniber states. Resort to the Charter to protect human rights suffers, however, fronı a number of limitations that should be kept in mind:

1. The Charter's luman rights provisions are very vague; in particular, they fail to define specific human rights. Since any international consensus as to their precise ineaning is therefore unlikely, it will be difficult to create uniformity of international human rights protection.

2. The legal protection of substantive rights derived from the Charter would entirely depend on, and be limited by, the procedures of national law. ${ }^{12}$

8. G.A. Res. 2200A (XXI), 21 U.N. GAOR Supp. 16 at 49, U.N. Doc. AV6546 (1966) [hereinafter cited as Covenants]. Thirty-five ratifications or accessions are needed for the Covenants to go into effect. As of Feb. 12, 1972, fifteen countries had signified their intention to be bound by both covenants; among them are two socialist states, five Latin-American states, three European states and five African and Middle-East states. U.N. Press Release L/T/812 (Feb. 11, 1972).

9. But see Grundoesetz (Basic Law), art. 25 (W. Ger. 1949), states:

The general rules of public international law shall be an integral part of federal law. They shall take precedence over the laws and shall directly create rights and duties for the inhabitants of the federal territory.

10. The Convention does not, for instance, include the social and economic rights set forth in the Universal Declaration of Human Rights, G.A. Res. 217 (III), U.N. Doc. A/810, at 71-77 (1948) [hereinafter cited as Universal Declaration] and the Covenants. (1970).

11. Cf. J. Carey, U.N. Protection of Civil and Political Riohts 11-12

12. For example, in the Federal Republic of Germany, international human rights could not, even if the Charter were ratified, be vindicated before the Constitutional Court. Cf. A. Bleckmann, supra note 2 , at $75 \& \mathrm{n} .78$, on the effect in Germany of the European Convention on Human Rights. 
3. The human rights provisions, even if self-executing, can only be applied in nember states that either generally accept ratified international treaties ipso facto as part of their domestic legal order or enact specific implementing legislation to give internal effect to the clauses concerned.

The third limitation substantially decreases the number of states in which domestic application is possible. Under the constitutional law of the United Kingdom, Ireland, ${ }^{13}$ the Scandimavian countries and almost all of the common law countries including Israel, a treaty that will modify existing law affecting private rights does not acquire the status of domestic law upon ratification. ${ }^{14}$ Instead, it inust receive parliamentary assent through an enabling or implementing act. ${ }^{15}$ None of these countries has as yet enacted legislation adopting or implementing the human rights provisions of the Charter. ${ }^{16}$

13. The Supreme Court of Ireland held in $R e$ O'Laighléis (Lawless) [1960] Ir. R. 93, 124-25 (1957), that even the European Convention cannot be given effect in Irish courts against conflicting domestic legislation. See Buergenthal, The Domestic Status of the European Convention on Human Rights: A Second Look, 7 J. INT'L COMM'N OF JURISTS 55, 76-77 (1966); J. FAWCETT, THE APPLICATION OF THE EUROPEAN Convention on Human Rights 13 (1969).

14. Cf. A. Bleckmann, supra note 2, at 41-44; A. Del Russo, International Protection of Human Rights 202-09 (1971) (on the European Convention on Human Rights); 1 D. O'CoNNell, International LAW 58-61 (2d ed. 1970); 1 L. OPPENHEIM, INTERNATIONAL LAW 40 (8th ed. H. Lauterpacht 1955); Buergenthal, supra note 13, at 75, 88-90, 93-94; Preuss, The Execution of Treaty Obligations Through Internal Law: System of the United States and Some Other Countries, 1951 A.S.I.L. PROCEEDINGS 82, 85-86.

15. The self-executing concept is unnecessary in cases where existing substantive legislation is adequate for enforcement of a treaty. But cf. Evans, supra note 2, at 186; Preuss, supra note 14, at 85-86.

16. Cf. Re Noble and Wolf, [1948] Ann. Dig. 302, 306, 308 (No. 100) (High Court, Ontario, Can.); Biswambhar Singh v. State of Orissa, 24 I.L.R. 425 (High Court, Orissa, India 1957).

The United Kingdom, for example, ratified the Charter without an act of Parliament specifically approving domestic application of the human rights provisions. Both Houses simply approved the ratification of the Charter on Aug. 23, 1945. This approval, however, has no legal effect upon the status of the Charter. Cf. D. O'ConNELL, supra note 14, at 60-61. During the debates, no mention was made of the doinestic inpact of the clauses. See 413 PARL. DEB., H.C. (5th ser.) 659-755, 861-950 (1950) and 137 PARL. Deb., H.L. (5th ser.) 104-50, 157-86 (1950). The commentary on the Charter (Cmd. No. 6666, 26 Accounts and Papers 389) contains only a quotation of art. 56.

In some cases, the United Kingdom implementing acts or orders in council have adopted the very language of the pertinent international provisions. Some of these orders, however, provide:

So far as they are by their nature capable of so doing the provisions of the

Treaty set out in the First Schedule hereto shall be and have effect as law. . . . A. BleckmanN, supra note 2, at 44 (emphasis added); see also id. n.117. Contrary to a widespread opinion, [see, e.g., A. KolLER, supra note 2], such phraseology may mean that the treaty in question can be interpreted as self-executing. A. BLECKMANN, supra note 2, at 42-44. As far as the human rights clauses are concerned, however, 
To be sure, failure to implement the Charter with legislation does not mean that the Charter has no legal effect upon domestic law. As I will show, the Charter can still influence judicial determination of public policy and imterpretation of the human rights provisions of the national law. These forms of imdirect application are not examples of self-execution, however, as I have defined that term. ${ }^{17}$

Self-execution of the human rights clauses is nevertheless a possibility in almost all civil law member states, the United States, the socialist countries, and some Third World countries. ${ }^{18}$ Whenever an international treaty is ratified through the appropriate constitutional procedures and accepted as the law of the land, as the Charter has been in inost of these countries, the question arises whether this treaty is binding upon the domestic courts without further legislative involvement. ${ }^{10}$ For instance, in the Federal Republic of Germany a treaty duly ratified by the President with statutory consent and authorization by the Bundestag $^{20}$ automatically has effect (Geltung) within the German legal order. ${ }^{21}$ In many of the other countries under discussion, including the United States, legal effect similarly follows autoniatically once the pre-

this question does not arise since no similar legislative measures have been enacted.

The United Nations Act of 1946, 9-10 Geo. 6, c.45, is merely designed to enable effect to be given to art. 41 of the Charter. On the other hand, articles 104 and 105, which are uniformly considered self-executing in the United States and the European civil law countries [See, e.g., B. SCHLÜTER, DIE INNERSTAATIICHE RECHTSSTELLUNG DER INTERNATIONALEN OROANISATIONEN 33-36 \& nn.184, 186 (1972)], have been implemented in the United Kingdom by the detailed provisions of the Diplomatic Privileges (United Nations and International Court of Justice) Order in Council [1947] STat. R. \& O. 520 (No. 1772). See also the International Organisations (Immunities and Privileges) Act of 1950, 14 Geo. 6, c.14.

For a discussion of the interesting Norwegian practice on legislation affecting domestic application of treaty provisions, see, with respeet to the European Convention on Human Rights, A. DEL Russo, supra note 14, at 206.

17. See text acconpanying notes 244-79 infra.

18. E.g., Argentina and other South-American countries, Austria, Cyprus, Belgium, Egypt, France, Greece, Italy, Japan, Luxembourg, Malta, Mexico, the Netherlands, Spain, Turkey, the United States, and the Federal Republic of Germany after accession to the U.N.

For references to legal theory and practice in those countries with respect to selfexecuting treaties see A. BLECKMANn, supra note 2, at 17-41; D. O'Connell, supra note 14, at 65-79; Evans, supra note 2, at 194-205; Preuss, supra note 14, at 85-96.

19. That acceptance of a provision as the law of the land does not dispose of the self-execution issue is emphasized by A. Koller, supra note 2, at 62 et seq. See Riesenfeld, The Doctrine of Self-Executing Treaties and GATT: A Notable German Judgment, 65 AM. J. INT'L L. 548, 549 (1971), discussing Judgment of Oct. 29, 1969, reported in 16 Aussenwirtschaftsdienst des Betriebs Beraters 93 (Tax Court Hamburg), a translation of which appears at 65 AM. J. INT'L L. 627.

20. GRUNDGESETZ (Basic Law) art. 59 (W. Ger. 1949). The Federal Republic of Germany will not be a United Nations member until 1973.

21. For a comprehensive discussion of the doctrines of adoption and transformation see Seidl-Hohenveldern, Transformation or Adoption of International Law into Municipal Law, 12 INT'L CoMP. L.Q. 88 (1963). 
scribed ratification prerequisites have been met. This does not necessarily mean, however, that the courts may directly apply the treaty provisions. ${ }^{22}$ Each provision, rather, has to meet several tests in order to be directly apphicable im the courts.

The source of standards for determining the applicability of the human rights clauscs thus becomes the problem. While the treaty provisions themselves may affect their apphcability, and while imternational law may contain its own standards for use in international courts, ${ }^{23}$ only the national foreign relations law of the forum states ultimately determines domestic application. Whether or not a norm of international origin must be applied by national courts depends in each country primarily on constitutional law, on the conditions set by the approving legislature, and, in most states, on customary rules developed by courts and legal writers. ${ }^{24}$ This follows from a well-established principle of international law: that unless otherwise specified im a treaty, states are generally free to decide low they are going to fulfill their imternational obligations. ${ }^{25}$ Accordingly, they can choose the Britisl model of special transformation or can automatically introduce imternational norms imto their domestic legal order and allow certain of these norms to be applied directly by their courts.

Since the legal orders vary substantially from state to state, there are quite a number of different doctrines, each einphasizing certain tests or combinations of tests. Unfortunately, even within inany states there

22. For the German position, see authorities cited note 18, supra; Riesenfeld supra note 19.

On the effect of treaty ratification in other conntries preserving the possibility of direct application, see A. BLECKMANN, supra note 2, at 57-66; A. Koller, supra note 2, at 62 et seq.; Cadoux, La supériorité du droit des Nations Unis sur le droit des Etats Membres, 63 Revue GÉnérale de Drort International Public 649, 662-63 (1959); Mosler, L'application du droit international public par les tribunaux nationaux, 91 ACAdémie de Drort InTERnational, RecueIl des Cours [RDC] 625, 663-69 (1957); de Visscher, Les tendances internationales des Constitutions modernes, 80 RDC 511, 558-62 (1952).

23. E.g., the Court of Justice of the European Communities, the International Court of Justice, and its predecessor. Cf. A. BLECKMANN, supra note 2, at 44-48, 103-08; A. KolleR, supra note 2, at 114 \& nn.1-3; O'CONNELl, supra note 14, at 54-55 n.57.

24. This is the view uniformly expressed by American authors. See, e.g., Evans, supra note 2, at 193; Preuss, supra note 14, at 96; Schachter, The Charter and the Constitution: The Human Rights Provisions in American Law, 4 VAND. I. REV. 643, 653-54 (1950-51). For the views of European authors see A. BlECKamanN, supra note 2, at 103-08; A. KollER, supra note 2, at 114 \& nn.1-3, 115-19.

25. See Mosler, supra note 22, at 629; Schachter, supra note 24, at 646-53; de Visscher, supra note 22, at 555 . For an evaluation of recent developments in the law of treaties, see Sørensen, Obligations of a State Party to a Treaty as Regards its Municipal Law in Human Rights in National and International Law, in Proceedings of tHe 2D InTERnational CONFERENCE on the European Convention 11 (A. Robertson ed. 1968). 
is no consensus on the applicable tests. Monists and dualists, legal writers and courts often differ substantially in their views, nraking it difficult to find out what the law is. Because of this diversity of opinion even within nations, the present inquiry, rather than proceeding on a country-by-country basis, will describe and evaluate the prevailing doctrines and speculate on the outcoine of applying each of thein to the human rights clauses. ${ }^{28}$

\section{II}

\section{The Human Rights Provision Under the Various Tests}

\section{FOR DOMESTIC APPLICATION}

Since tests for domestic applicability are interrelated, are based on similar rationales, and sometimes are merely terminologically different aproaches to the same phenomenon, it is difficult to organize them systematically. Some tests follow logically from the nature of the problem or are derived from such basic primciples as the rule of law; these tests enjoy a widespread application. Others nierely reflect peculiarities of domestic legal orders, such as the structure of power distribution among the various branches of government.

A helpful, though perhaps superficial, distinction can be niade between objective and subjective criteria. Objective criteria concern the character, language, content, and context of the norm itself, while subjective criteria look to the intent of the parties to the treaty or of the approving legislature. For reasons of convenience, this study first analyzes the human rights clauses under the one uniformly accepted objective test: the obligatory nature of the provisions. It then proceeds to the subjective tests and finally examines the remaining objective tests, the most crucial of which is the test of precision.

\section{A. The Obligatory Character of the Provisions}

The various national doctrines agree that treaties are only selfexecutimg to the extent they contain norms that create specific obligations for the parties. ${ }^{27}$ This follows from the simple axiom that a provision that lacks binding force on the international level but is rather to be regarded as a guiding principle, statement of purpose or the like

26. This approach is also appropriate because of the absence of court decisions, except in North America, dealing with the domestic status of the provisions in question. Any atteinpt to delineate the actual tests applied to the provisions would therefore be futile.

27. E.g., A. BlECKMANN, supra note 2, at 238; H. LAUTERPACHT, INTERNATIONAL LAW AND HUMaN RigHrs 158 (1950); Mosler, supra note 22, at 655-57; Preuss, Some Aspects of the Human Rights Provisions of the Charter and their Execution in the United States, 46 AM. I. INT'L I. 289-96 (1952); Wright, supra note 4, at 69-70. 
cannot be executed or incorporated as a rule bimding upon the domestic courts. $^{28}$

Even if a treaty provision is obligatory, it is not necessarily directly applicable; the provision may merely import a contract between the states or may fail to meet the remaining tests. The contract possibility suggests that, for a provision to be self-executing, the created obligation must be somehow related in purpose or content to the domestic sphere. ${ }^{29}$ The theoretical question whether this requirement should be considered an integral part of the self-executing concept or a separate issue of logical priority ${ }^{30}$ need not be decided here. It should be noted, however, that in either case the obligatory nature of a provision can be uniformly established by interpretation of the relevant provisions, without reference to national standards.

The problein at stake, therefore, is whether the human rights provisions of the Charter create for the member states any specific obligation to grant to their subjects the rights and freedoms mentioned in the preainble and text of the Charter. ${ }^{31}$ A first look at these provisions and their contexts reveals that almost all the formulas define purposes and functions of the United Nations and its main organs, rather than the obligations of its members. Articles 55 and 56, however, are different: they are seemingly concerned with actions of the member states outside of the organization itself. From the time of their drafting their impact has been the subject of widespread international dispute.

Although the major arguments advanced both in favor of and against construing articles 55 and 56 as creating domestic obligations for member states are well known, it may be appropriate to discuss them briefly in light of the accepted canons of construction set forth in the Viema Convention on the Law of Treaties ${ }^{32}$ and to consider recent developments.

28. Authorities cited note 25 supra; Schachter, supra note 24, at 646.

29. A. BLECKMANN, supra note 2, at 238.

30. According to Wright, supra note 4 , at $69-70$, the self-executing concept has a different meaning in constitutional and international law. In the latter context, the term "non-self-executing" refers to provisions that do not contain obligations on the part of the members-e.g., definitions of organizational functions and purposes.

31. Schachter, supra note 24 , at 646 , refers to a "legal obligation with respect to the observance of human rights."

32. U.N. Doc. A/C. 39/27 (1969); text also in Official Documents, 63 AM. J. INT'2 L. 875 (1969) [hereinafter cited as Vienna Convention]. For the impact of arts. 31-33 on the interpretation of the Charter, see arts. 4 and 5 of the Vienna Convention.

A comprehensive survey of international authorities on interpretive methods is contained in U.S. Dep'T of STate, Pub. No. 8547, printed in 14 Digest of INT'L LAW 353-410 (M. Whiteman ed. 1970) [heremafter cited as 14 D.I.L.]. For a study on the international canons of interpretation see R. BERNHARDT, DIE AUSLEGUNG VöLKERRECHTIICHER VERTRÄGE INSBESONDERE IN DER NEUEREN RECHTSPRECHUNG INTERNATIONALER 


\section{The Arguments Against the Human Rights Provision as Obligatory}

In the late forties and early fifties, a number of legal writers maintained that the human rights clauses are not legal norms but rather a program of principles, ${ }^{33}$ a statement of purposes and aims ${ }^{34}$ or an obligation merely to cooperate with the organization on the international level. ${ }^{35}$ Hans Kelsen even considered article 56 "meaningless and redundant."36 Similarly, some American courts have found that the pertinent provisions "are inerely indicative of a desirable social trend and an objective devoutly to be desired by all well-thinking peoples" ${ }^{37}$ and "have nothing to do with domestic matters."

In support of these conclusions, a small set of interrelated arguments has been advanced. The arguments chiefly focus on:

GERICHTB (1963).

But cf. Newman, Interpreting the Human Rights Clauses of the UN Charter, 5 Human Rights J. 283 (1972): "The 1969 Vienna Convention . . . may be or become 'Iaw'; but Articles 31-33, its identified rules of interpretation, probably will have no more effect on the human rights clauses than so-called rules of statutory interpretation have had on the U.S. Bill of Rights." Newman advocates that interpreters should instead be governed by the International Bill of Human Rights.

33. Kunz, The United Nations Declaration of Human Rights, 43 AM. J. INT'L L. 316, 317-18 (1949) [heremafter cited as Declaration]; Kunz, Present-Day Efforts at International Protection of Human Rights: A General Analytical and Critical Introduction, 1951 A.S.I.L. Proceedings 109, 115 and n.8 [heremafter cited as International Protection].

34. Hudson, Integrity of International Instruments, 42 AM. J. INT'L L. 105, 105-08 (1948).

35. R. BRUNET, LA GARANTIE INTERNATIONALE DES DROTTS DE L'HOMME D'APRES la Charte de San - Francisco 164 (1947) citing R. Asher, W. Kotschnio et al., The United Nations and Promotion of General Welfare 659 (1957); P. Drost, Human Rights as Legal Rights, the Realization of Individual Human Rights in Positive International Law 29-31 (1951); J. Robinson, Human Riohts and Funda. mental Freedoms in the Charter of the Unted Nations-A Commentary 62-64, 72-73 (1946) (leaving open, at 105, the possibility of further positive developments); Note, The Declaration of Human Rights, the United Nations Charter and their Effect on the Domestic Law of Human Rights, 36 VA. L. REv. 1059, 1079 (1950); Hudson, Charter Provisions on Human Rights in American Law, 44 AM. J. INT'L L. 543, 544 (1950). In 1947, a similar view was expressed by the Legal Adviser to the State Department. See the quotation in H. LAUTERPACHT, supra note 27, at 149 n.10.

See also C. de Visscher, Theory and Reality in Public International Law 126 (1957); Preuss, supra note 27, at 295; Rix, Human Rights and International Law, 1949 A.S.I.L. Proceedings 46-58; Sandifer, The International Protection of Human Rights: The United Nations System, 1949 A.S.I.L. PROCEEDINGS 59-61.

36. H. Kelsen, The Law of the United Nations 100 (1950). See also $i d$. at 29-33 (analysis of the pertinent provisions other than art. 56).

37. Sipes v. McGhee, 316 Mich. 614, 628, 25 N.W.2d 638, 644, [1947] Ann. Dig. 96, 97 (No. 35) (1947).

38. Kemp v. Rubin, 188 Misc. 310, 315-16, 69 N.Y.S.2d 680, 686 (Sup. Ct. 1947), affd mem., 273 App. Div. 789, 75 N.Y.S.2d 768, rev'd and complaint dismissed mem., 298 N.Y. 590, 81 N.E.2d 325 (1948). The court continues: "In fact, Article 2, section 7, of the United Nations Charter . . . expressly so provides." Id. at 686. 
1. the meaning of the "pledge to cooperate" in article $56^{39}$

2. the non-intervention principle of article 2 , paragraph 7 and the failure to provide for compulsory powers of the United Nations in human rights, both bearing on the interpretation of articles 55 and $56 ;^{40}$ and

3. the failure of article 55(c) to specify particular human rights and fundamental freedoms. ${ }^{41}$

Soine of the rationales for denying obligatory effect to articles 55 and 56 seem to neglect the well-established principle that "[a] treaty shall be interpreted in good faith in accordance with the ordinary meaning to be given to the terms of the treaty in their context and im the light of its object and purpose." 42 Kelsen's starting point, for instance, that "to take action in cooperation with the Organization" means to cooperate with the organization by taking action, shifts the emphasis froin separate action to cooperation in a way not required by, and probably not consistent with, the ordinary meaning of the terms in their context. ${ }^{43}$

Similarly, nothing in article 55 supports Kelsen's second premise -that the purposes set forth therein are only meant to encourage cooperation among members. ${ }^{44}$ Although Kelsen concludes that article 56 is an "empty tautology," nnerely creating an obligation of the meinbers to cooperate with the United Nations in order to bring about cooperation among themselves, ${ }^{45}$ this is clearly inconsistent with a literal construction: article 56, by mentioning the "purposes set forth in article 55 ," rather seems to refer to the substantive purposes of the organization itself, among which are promoting respect for and observance of human rights. ${ }^{46}$ Kelsen's position also fails to interpret in the light of the purposes of the Charter; imstead, it results in a construction rendering a provision repetitive, superfluous, and meaningless. ${ }^{47}$

39. H. KELSEN, supra note 36, at 99-100; J. RoBINSON, supra note 35 , at $62-64$, 72-73; Hudson, supra note 34, at 544; Sandifer, supra note 35, at 61.

40. H. KeLsEN, supra note 36; Kemp v. Rubin, 188 Misc. 310, 315-16, 69 N.Y.S.2d 680, 686 (Sup. Ct. 1947).

41. P. Drost, supra note 35, at 29; H. KELSEN, supra note 36, at 29-30; Kunz, International Protection, supra note 33, at 115.

42. Vienna Convention, supra note 32, art. 31, para. 1. 647.

43. For a critical analysis of Kelsen's position see Schachter, supra note 24, at

44. But cf. M. O. Hudson's statements in the U.N. International Law Commission quoted by H. LAUTERPACHT, supra note 27 , at $154 \mathrm{n} .20$, and by Schwelb, The International Court of Justice and the Human Rights Clauses of the Charter, 66 AM. J. INT'L L. 337, 338 \& in.2-4 (1972). For a criticism of Hudson's view see Wright, supra note 4 , at 73.

45. H. KELSEN, supra note 36 , at 99.

46. See H. Guradze, Der Stand Der MenschenRechte M VölkerRecht 110-11 (1956).

47. Id. at 108, 110, calling Kelsen's conclusion absurd; Wright, supra note 4, at 
Kelsen argues in addition that article 56 cannot be construed as an obligation to comply with the recommendations of the General Asseinbly, since General Assembly resolutions are not mandatory ${ }^{48}$ and simce article 2, paragraph 7 denies any interventional powers to the organization. ${ }^{49}$ The question of the organization's interventional fnnctions and compulsory powers need have no bearing at all, however, on the existence and nature of the obligation created by article $56^{50}$ Even if the states are not required to comply with General Assembly recommendations, they may be under an obligation to observe human rights "im cooperation with the Organization." And according to international law doctrine recognized by the vast majority of governments, courts, and legal writers, international legal obligations are not affected by a lack of sanctions for conduct contrary to an agreement. ${ }^{51}$ A systematic interpretation of article 56 will not, therefore, warrant rejecting the argument that it is mandatory. ${ }^{52}$ On the contrary, the emphasis placed on the promotion of human rights throughout the Charter, particularly in its preamble and in article 1, may reaffirm the construction of article 56 as mandatory.

\section{Interpretation of Articles 55 and 56 as Obligatory}

This brings us back to the crucial question of the positive meaning to be given to article 56 in accordance with the interpretive rules mentioned above. The problem thus becomes whether the language, the context, the purpose, and, subsidiarily, the intent of the franiers support the view that article 56 involves a domestic obligation to protect human rights.

The foregoing review of Kelsen's reasoning suggests that article 56 must be read im connection with article 55 as containing a pledge of the members to take joint and separate action in cooperation with the organization to achieve respect for, and observance of, human rights and fundamental freedoms for all without distinction as to race, sex, language, or religion. .53 The ordimary meaning of "pledge" is a solemn

72-73. See generally the Corfu Channel Case (Merits), [1949] I.C.J. 1, 23-24, 26, on interpretive principles.

48. U.N. Charter, art. 2, para. 7.

49. H. KELSEN, supra note 36 , at 99-100.

50. H. LAUTERPACHT, supra note 27 , at 148 n.8, 166; Lauterpacht, The International Protection of Human Rights, 70 RDC 5, 16 n.1 (1947); Schachter, supra note 24, at 648; cf. Wright, supra note 4, at 74 .

51. H. GURADZE, supra note 46, at 110; H. LAUTERPACHT, supra note 27 , at 34; Schachter, supra note 24, at 649; cf. P. JEssup, A MODERN LAW of NATIONs 4 et seq. (1948). But see H. KELSEN, supra note 36, at 88, 96, where the author clarifies his theoretical premises with regard to international sanctions as constituent elements of international law.

52. See Schachter, supra note 24, at 647-49.

53. See Wright, supra note 4 , at $70-73$. 
promise or undertaking ${ }^{54}$ that clearly establishes some legal obligation for the members. Moreover, in view of the term "separate action," it is difficult to confine this obligation to acts of general cooperation within the institutional framework of the United Nations-cooperation with the Human Rights Commission or other bodies working under the organization's auspices, for example. ${ }^{55}$

Only a construction poimting to action in a broad sense, including in the domestic sphere, ${ }^{56}$ effectuates the inajor purpose of the provisions, the promotion of human rights." "Separate action in cooperation" may be construed to mean "in commumication with the Umited Nations and in accordance with its primciples and purposes."58 Such a construction would, as Qumcy Wright points out, imply, as a minimum, abstention from separate discriminatory action. ${ }^{59}$ Yet, while the states' behavior with respect to human rights would be generally limited and regulated by their obligation to achieve respect for and observance of human rights, ${ }^{60}$ each state would be legally free to implement or reject specific recommendations of the United Nations.

Even if it were conceded that an objective interpretation ${ }^{61}$ leaves the meaning of the pledge to take action in cooperation still somewliat questionable, recourse to supplementary means of interpretation, particularly the preparatory work for the Charter, ${ }^{62}$ provides substantial support for my construction. While the records of the San Francisco

54. The French text reads: "Les membres s'engagent . . à agir." See Schachter, supra note 24 , at 648 \& nn.21-23 (legislative history of art. 56).

55. But cf. J. RoBINSON, supra note 35, at 62-63: "[T] me members are bound only to cooperate loyally in all efforts of UNO in bringing about the realization of the lofty purposes contamed in Article 55." See also P. Drost, supra note 35, at 30.

56. See H. GURADZE, supra note 46 , at 109-10.

57. See Schachter, supra note 24 , at $652-53$. Schachter refers to the rule of effectiveness or liberal construction of treaties as recognized by the U.S. Supreme Court. Id. at 652 n.48. This rule, however, is not explicitly mentioned in arts. 31 and 32 of the Vienna Convention. Instead, art. 31 refers to the similar method of teleological interpretation. See generally 14 D.I.L., supra note 32, at 380-84. But cf. H. LAUTERPACHT, supra note 27 , at 150 .

58. Cf. the statement of Prime Minister Attlee before the House of Commons on Aug. 22, 1945, concerning arts. 55 and 56: "... [T]he raising of standards is not a matter that must wait until there has been international agreennent; it ineans that all can go forward, everyone in their own country aud thus in cooperation try to get uniformity and a moving forward together." 413 PARL. DEB. H.C. (5th ser.) 666 (1950).

59. Wright, supra note 4 , at 72 .

60. I G. DAHM, VöLKERRECHT 423 (1958), maintains that a violation of human rights is contrary to their promotion and consequently violates the Charter. Similarly, Schachter, supra note 24 , at 650 , states that the formulation of the cooperation principle does not confer unlimited discretion on the meinbers.

61. I.e., an interpretation in accordance with the canons contained in art. 31 of the Vienna Convention. See text accoinpanying note 42 supra.

62. Vienna Convention art. 32. For details concerning this method see 14 D.I.L., supra note 32 , at 386-99. 
meetings on the drafting of the Charter do not contain any opinions as to the ineaning of "cooperation with the Orgainzation," they inake it clear that the framers continually attached importance to the words "separate action;" the qualifying words "in cooperation" were mainly intended to prevent direct United Nations intervention in domestic, particularly in economic, affairs rather than to limit the obligation of the menbers to observe human rights. ${ }^{63}$ Hence, a subjective interpretation appears to confirm the meaning established by the foregoing objective interpretation.

The remaining point of controversy, the lack of precision in delimiting the regulated state behavior, cannot be considered a serious obstacle. $^{64}$ The ordinary meaning of the words "achievement of respect for, and observance of," human rights implies that states should atteinpt to protect human rights ${ }^{65}$ as well as abstain from violating thein. ${ }^{66}$ Thus, the obligation must require nember states to establish devices ensuring the effective enforcement of these rights. On the other hand, any atteinpt to maintain doctrines and practices destructive of human rights would be incoinpatible with the promise to promote respect for, and observance of, human rights and fundamental freedoms. ${ }^{67}$

This specification still leaves considerable latitude to the states to implement the clauses. But, the protection of human rights "for all without distinction as to race, sex, language, or religion" provides at least one fairly concrete, precise standard governing certain state be-

63. The text is a compromise between the views of the Australian and United States delegations. See M. Ganjl, International Protection of Human Rights 11718 (1962); Goodrich, Hambro \& Smons, Charter of the United Nations 380-82 (3rd ed. 1969); H. GURADZE, supra note 56, at $105 \&$ n.20, 106, 110; Schachter, supra note 24, at 649-51 \& nn.33-38; Wright, supra note 4, at 72-73 \& n.32. But cf. $\mathrm{H}$. KELSEN, supra note 36 , at $100.02 \mathrm{n} .9$, where too mueh weight appears to be given to the position taken by the U.S. delegation. For a very comprehensive analysis of the legislative history see J. ROBINSoN, supra note 35, at 17 et seq.

See also Huston, Human Rights Enforcement Issues of the United Nations Conference on International Organization, 53 Iowa L. Rev. 272, 283-85 (1967); McDougal and Bebr, Human Rights in the United Nations, 58 AM. J. INT'L L. 603, 613 (1964); Comment, U.N. Charter Invalidates Alien Land Law, 2 Stan. L. Rev. 797, 802-04 (1950).

64. See M. Ganji, supra note 63 , at 122-23; 1 P. GuggenheIM, Trarté DE Drolt INTERNATIONAL PUBLIC 301-02 (1953); H. LAUTERPACHT, supra note 27, at 148-49; OPPENHEM, supra note 14 , at 741 n.4 (comparison with the sweeping provisions of the Peace Treatios of 1947); Waldock, General Course on Public International Law, 106 RDC 5, 198 (1962). But see authorities cited note 41 supra.

65. M. GANJI, supra note 63, at 132.

66. G. DAHM, supra note 60 , at 423.

67. McDougal \& Leighton, The Rights of Man in the World Community: Constitutional Illusions Versus Rational Action, 59 YALE L.J. 60, 68, 87 \& n.153 (1949). See Waldock, supra note 64, at 200. 
havior: ${ }^{88}$ the state may not itself deny rights to one group because of its race, sex, language or religion while allowing other groups those rights, because such an action would be inconsistent with protecting rights without discrimination.

Moreover, the concept of human rights is not an entirely new invention by the framers of the Charter. It has a core of ineaning ${ }^{69}$ provided by a continuously developing body of general principles recognized by civilized nations and by international customary law. ${ }^{70}$ These sources provide further specification of implications of the human rights clauses, ${ }^{71}$ making it difficult to deny that the clauses can be interpreted precisely enough to liave an effect on the states' doinestic behavior.

Finally, considerable support for the construction advocated above is provided by the subsequent practice of the organs and members of the United Nations in application of the human rights clauses. ${ }^{72}$ As early as 1949, a inajority of the meinbers of the United Nations International Law Commission seemed to accept the human rights clauses as creating an obligation binding on nember nations. ${ }^{73}$ Other representatives have expressed the same view in the General Assembly and its committees. ${ }^{74}$ It is of particular interest that the representative of the United States observed at the Third General Assembly in 1949 that "we have all committed ourselves to promote respect for and observance of human rights and fundamental freedoms." $" 75$ This appears to be a recognition that the position taken by the United States delegation in San Francisco agaimst making the human riglits provisions binding was not consistent with the language ultimately adopted. The United States' approval of numerous General Assembly resolutions presuppos-

68. See G. DAHM, supra note 60 , at 424 ; H. LAUTERPACHT, supra note 27 , at 153; Schachter, supra note 24, at 651 . For details see text accompanying notes 169227 infra.

69. Schachter, supra note 24, at 651-52.

70. This is emphasized by Waldock, supra note 64, at 198. See I.C.J. STAT. art. 38. For an attempt to establish the minimum content of the human rights concept see M. GaNII, supra note 63 , at 123-131; cf. G. DaHM, supra note 60 , at $423-24$. For further discussion see text accompanying notes 169-227 infra.

71. Art. 31, para. 3 of the Vienna Convention provides: "There shall be taken into account, together with the context .... (c) any relevant rules of international law applicable in the relations between the parties." See also note 32 supra.

72. Art. 31, para. 3(b) of the Vienna Convention recognizes analysis of the subsequent practice of the parties as another available method of interpretation. For a general survey of this method see 14 D.I.L., supra note 32, at 399-406.

73. See H. Lauterpacht, supra note 27 , at 154 n.20, quoting J. Brierly and G. Scelle; M. GaNJI, supra note 63, at 131 n.58. But see note 44 supra.

74. For references see Schachter, supra note 24, at 649 n.32.

75. Statement by Benjamin V. Cohen, U.S. Delegate to the General Assembly, Violation of Human Rights in Bulgaria, Hungary and Rumania, 20 DEP'T STATE BUtL. $611,613$. 
ing binding Charter obligations in the field of human rights and fundamental freedoms suggests the same conclusion. ${ }^{70}$

Additionally, the political organs of the Umited Nations have interpreted the human rights clauses as a whole to constitute legal obligations. ${ }^{77}$ Indeed, former Secretary General $U$ Thant referred to these clauses as "perhaps the boldest innovations of the Charter-the unconditioned and universal obligation in regard to human rights and fundamental freedoms." ${ }^{88}$

A recent confirmation of particular significance comes from the judicial organ of the United Nations, the International Court of Justice. On June 21, 1971, in an advisory opinion condemning the practice of apartheid, ${ }^{79}$ the court spoke of "the international obligations assumed by South Africa under the Charter of the Umited Nations. ${ }^{80}$ South Africa, the court said, had "pledged itself to observe and respect, in a territory having an international status, human rights and fundamental freedoms for all without distinction as to race," and to deny human rights on the basis of race is "a flagrant violation of the purposes and principles of the Charter."

In speaking of a violation of the purposes and principles of the Charter, the court presumably did not intend to convey the idea that only the article 1, paragraph 3 provision that one of the purposes of the United Nations is to protect human rights had been violated. The explicit reference to the pledge of the nnembers contamed in article 56 may indicate that the court meant to determine a violation of the human

76. H. GURADZE, supra note 46 , at 111 . Some important early resolutions are, e.g., G.A. Res. 44, U.N. Doc. A/64 at 68 (1946) (treatment of Indians in the Umion of South Africa); G.A. Res. 285, U.N. Doc. A/900 at 34 (1949) (violations of human rights by the U.S.S.R. by preventing Russian wives from joining their husbands abroad); G.A. Res. 616, 7 U.N. GAOR Supp. 20, at 8, U.N. Doc. A/2361 (1952) (explicitly referring to art. 56 while censoring apartheid politics in South Africa). See also G.A. Res. 917, 10 U.N. GAOR Supp. 19, at 8, U.N. Doc. A/3116 (1955) and G.A. Res. 1016, 11 U.N. GAOR Supp. 17, at 5, U.N. Doc. A/3572 (1956).

For more recent resolutions and decisions of the General Assembly and other U.N. bodies see U.N. Doc. E/CN. 4/923/Add. 3, Dec. 3, 1970 ("Decisions taken by UN bodies concerning provisions relevant to the question of the violation of lruman rights and fundamental freedoms ....").

77. J. Brownlie, Principles of Public International Law 463 (1966). Sec, e.g., J. CAREY, supra note 11; H. GURADZE, supra note 46 , at 74-98 (review of U.N. humau rights cases); Schwelb, supra note 54, at 341-46 (short review of U.N. human rights practice).

78. Opening statement at the 45th session of ECOSOC, Geneva, July 8, 1968, U.N. Press Release SG/SM/971-ECOSOC/2474 (1968).

79. Advisory Opinion on Legal Consequences for States of the Continued Presence of South Africa in Namibia (South West Africa) notwithstanding Security Council Resolution 276 (1970), [1971] I.C.J. 16, 66 AM. J. INT'L L. 145 (1972).

80. Id. para. 129,66 AM. J. INT'L L. at 180.

81. Id. para. 131, 66 AM. J. INT'L L. at 180-81. 
rights clauses as a whole. ${ }^{82}$ One can thus conclude that the court endorses the virtually universal view that the Charter imposes legal obligations on the members with respect to domestic behavior affecting human rights. ${ }^{83}$

A nuniber of national courts have also recognized an international obligation under the Charter. Three Canadian decisions have done so more or less explicitly, ${ }^{84}$ as has a decision of the High Court of Orissa, India. ${ }^{85}$ Further, the Supreme Court of California in Fujii v. State seems to have recognized some international obligation on the part of the United States, since it acknowledged that "[t]he member nations have obligated themselves to cooperate with the international organization in promoting respect for, and observance of, human rights." 86 Yet at the same time, the court, rather ambiguously, remarks that article 56 represents only a "moral commitment" and that its provisions "lack ... mandatory quality." 87

An explicit, authoritative acknowledgement of legal obligations under article 56 is contained in the concurring opimions of Justices Black and Murphy, joimed respectively by Justices Douglas and Rutledge, in Oyama v. California. ${ }^{88}$ "[W]e have recently pledged ourselves," Justice Black wrote, "to cooperate with the United Nations to 'promote . . . universal respect for, and observance of, human riglits and fundamental freedoms for all without distinction as to race, sex, language or religion." " To enforce state laws which bar land ownership and occupancy by aliens, Justice Black reasoned, would be to fail to be faithful to that pledge. ${ }^{89}$ Justice Murphy expressed a similar view:

This nation has recently pledged itself, through the United Nations Charter, to promote respect for, and observance of, human

82. Schwelb, supra note 44 , at 349 . The positive response of both the Security Council and the General Assembly to the Court's advisory opinion is reported id. at 351.

83. See also the dissenting opinion of Judge Tanaka in the South West Africa Cases (Second Phase), [1966] I.C.J. 4, 287-90, and the separate opinion of Judge van Wyk, id. at 165-66.

84. Re Drummond Wren, [1943-45] Ann. Dig. 178, 179 (No. 50) (High Court, Ontario, Can. 1945); Re Noble and Wolf, [1948] Ann. Dig. 302, 305 (No. 100) (High Court, Ontario, Can.); for the Court of Appeals decision in $R e$ Noble and Wolfe see [1948] Ann. Dig. at 308.

85. 24 I.L.R. 426-27 (High Court, Orissa, India 1957).

86. 38 Cal. 2d 718, 722, 242 P.2d 617, 621 (1952). The District Court of Appeals decision had explicitly affirmed the obligatory nature of the human rights clauses. 217 P.2d 481 (2d Dist. 1950). For a different interpretation of the supreme court decision see L. OPPENHEIM, supra note 14 , at 741 n.4.

87. 38 Cal. $2 d$ at 724,242 P.2d at 622 .

88. 332 U.S. 633, [1949] Ann. Dig. 247 (No. 79) (1948).

89. Id. at 649-50, [1949] Ann. Dig. at 250. 
rights and fundamental freedouns for all without distinction as to race, sex, language and religion. The Alien Land Law stands as a barrier to the fulfillment of the national pledge. Its inconsistency with the Charter, which has been duly ratified and adopted by the Umited States, is but one more reason why the statute must be condemned. ${ }^{90}$

Finally, it should be noted that most of the remaining pertinent decisions of American courts, while denying the self-executing nature of the clauses or their impact on public policy, do not deal with their obligatory effect in international law. ${ }^{01}$

\section{Conclusions}

The foregoing analysis suggests that the obligatory nature of the human rights clauses is today outside the realm of serious controversy. It is based on established principles of construction, among which interpretation in good faith is of particular importance, and is now endorsed by the overwhelming majority of international legal writers. ${ }^{92}$

90. Id. at 673, [19491 Ann. Dig. at 251. For discussion of the Oyama decision see, e.g., H. GURADZE, supra note 46, at 114-15.

91. Rice v. Sioux City Memorial Park Cemetery, Inc., 245 Iowa 147, 60 N.W. $2 \mathrm{~d}$ (1953), affed by equally divided court, 348 U.S. 880 (1954), vacated on rehearing and cert. dismissed, 349 U.S. 70 (1955); Vlissidis v. Anadell, 262 F.2d 398, 400 (7th Cir. 1959), 28 I.L.R. 463; Hitai v. Immigration and Naturalization Service, 343 F.2d 466, 468 (2d Cir.), cert. denied 382 U.S. 816 (1965); Paulimg v. McElroy, 164 F. Supp. 390, 393 (D.D.C. 1958), aff'd 278 F.2d 252 (D.C. Cir. 1960), cert. denied 364 U.S. 835 (1961); Camacho v. Rogers, 199 F. Supp. 155, 158, 32 I.L.R. 368, 369 (S.D.N.Y. 1961). But see Namba v. McCourt, 185 Ore. 579, 604, 204 P.2d 569, 579 (1949) (recognizing a legal obligation under art. 56).

92. Kunz's contention that "all scholars agree that the Cliarter proclaims merely a principle, states only a program whicl needs translation mto norms of intcrnational law," [supra note 33, at 115] was incorrect even in 1951. See, e.g., Schachter, supra note 24; H. LAUTERPACHT, supra note 27; Wriglit, supra note 4.

Besides the authors previously cited (Dahm, Guggenheim, Guradze, Lauterpacht, McDougal, Newman, Oppenheim, Schacltter, Schwelb, Sohn, Waldock, Wright) see, e.g. Commission to Study the Organization of Peace, 18th Report, The United NaTIONS AND HUMAN RIGHTS 4 (1968) [heremafter cited as REPORT]; A. DEL Russo, supra note 14, at 33-34; P. JESSUP, supra note 51 at 91; Malintoppi, L'art. 56 della Carta delle Nazione Unite, 44 Rivistadi Diritto Internationale 426-32 (1961) (with a critique of Kelsen's reasoning at 427-28); Markovic, Implementation of Human Rights and the Domestic Jurisdiction of States, in International Protection of Human Rights, in Proceedings of the 7Th Nobel Symposium, SEPT. 25-27, 1967, at 47, $50-52$ (1968); Sohn, United Nations Machinery for Implementing Human Rights, 62 AM. J. INr'L L. 909 (1968) [hcreinafter cited as Machinery]. Sohn refers to the Montreal Stateinent of the Assembly for Human Rights of March 27, 1968, which "expressed the general consensus of international experts that the 'Charter of the United Nations, the constitutional document of the world commumity creates binding obligations for meinbers of the Umited Nations with respect to human rights.' "Cf. Sohn, Protection of Human Rights Through International Legislation, in I AMrCORUM DISCIPULORUMQUE LIBER Festschrft for R. Cassin, at 325-26 (K. Vasak ed. 1969) [hereinafter cited as Protection]; Brownlie, supra note 77, at 463. 
The clauses thus import some legal obligation for member states with respect to domestic behavior affecting human rights. While the specific content of this obligation, the prescribed and prohibited behavior, the internal addressee of the rule, and the individual human rights protected need further elaboration through interpretation, it is at least clear that the national courts or government agencies may not reject any direct application of the human rights provisions on the grounds that the provisions are not obligatory.

This brimgs us to a second significant consideration. Without inquiry into the theoretical distinction between traités contrats and traités lois $^{, 93}$ we can say that because articles 55 and 56 are binding upon all meinbers they must be regarded as international legal norms. ${ }^{94}$ The establishment of a treaty provision as a legal norm is the only theoretically valid rationale for its domestic application as a rule of law bindimg on the courts..$^{95}$ Thus, once a treaty provision is established as a legal norm, a presumption in favor of its direct apphication arises, ${ }^{96}$ and any additional tests established by the national legal orders become, logically, exclusionary tests-tests determining whether a norm is not to be directly applied because of some peculiar fact. ${ }^{97}$ This consideration may have some impact on the courts' treatment of the human rights clauses, requiring them to administer legal doubts in favor of applying the clauses.

A final observation may be appropriate. The concept of selfexecuting treaties is internationally known but has developed at varying levels of complexity. In many instances, the courts have simply applied treaty norms without any reference to additional tests. ${ }^{98}$ Such a naive approach in this context would approve direct application of the human rights provisions without further investigation. The increasing sophistication of courts in applying treaties demands a closer look, however, at the remaining tests and their impact on the human rights clauses.

But cf. Wright, Treaties as Law in National Courts with Special Reference to the United States, 32 IND. L.J. 1, 6 (1956). See also Preuss, supra note 27, at 290-95; J. GREEN, THE UNITED NATIONS AND HUMAN RIGHTS 18-19 \& n.20 (1956).

93. For a discussion of these concepts see, e.g., A. BLECKMANN, supra note 2, at 246.

94. The notion "legal norm" is used as an equivalent to "rule of law." For an analysis of the criteria for international legal norms see A. BLECKMANN, id. at 246-52; cf. H. GURADZE, supra note 46, at 112-13.

95. A. BLECKMANN, supra note 2 , at 254-55.

96. This is true at least from a monistic viewpoint.

97. E.g., For the concept of Ausschlussgrïnde, see A. BLECrMANn, supra note 2, at 255; cf. Wright, supra note 4, at 69.

98. For examples see A. BleCKMANn, supra note 2, at 19-20, 33; A. Koller, supra note 2, at 95, referring, inter alia, to the Swiss practice under art. 113, para. 3 of the Federal Constitution. 
B. Subjective Tests of Self-Execution of the Human Rights Provisions

\section{The Intent of the Parties}

A comparative survey of the criteria for self-execution shows that courts and legal writers in many countries emphasize analysis of the intent of the parties as the primary means for determining the direct applicability of treaty provisions.90 Among the numerous formulas designed to determine what must have been intended for direct application to follow, some require explicitly an intent that the provision be self-executing. Others focus on an intent to meet the remaining objective tests of direct application-that is, an intent to protect individuals, confer rights and obligations upon them, affect the legal position of mdividuals, create justifiable norms binding on and enforceable by the courts and applicable to imdividuals, ${ }^{100}$ provide remedies to individuals, allow thein to invoke the treaty, address themselves to the individuals rather than to the legislature, and the like. ${ }^{101}$

In Europe this subjective approacl can be traced back to the advisory opinion of the Permanent Court of International Justice in the Jurisdiction of the Courts of Danzig case; ${ }^{102}$ it was apparently encouraged by the European Convention on Human Rights and the Treaties of Rome, which seemed to reflect clearly an intent that they be directly applicable. ${ }^{103}$

In the United States, the intent doctrine was first enunciated by the Supreme Court in United States $v$. Percheman, ${ }^{104}$ where the selfexecuting nature of article 8 of the Treaty of Amity, Settlement and Limits of 1819 between the United States and Spam was recognized

99. This is true especially in the United States and Europe. See, on the United States position, Restatement (SECOND) of Foreign ReLatrons LAw OF TIE UNITED STATES $\$ 141$ (1965), providing that in order to be self-executing a treaty must manifest "an iutention that it shall becone effective as domestic law of the United States."

See also 14 D.I.L., supra note 32, at 309, citing a memorandum of former Assistant Legal Adviser to the State Department S.D. Metzger emphasizing the intent of the parties; McLaughlin, The Scope of the Treaty Power in the United States, 42 MinN. L. REv. 709, 748 (1958); Comment, U.N. Charter, supra note 63, at 806.

For a coniprehensive discussion and numerous references on European treatment of interest, see A. BleCKMANN, supra note 2, at 17-41, 157-81; A. Koller, supra note 2 , at $82,97-100 ; M$. WAELBROECK, TRATtés INTERNATIONAUX ET JURIDICTIONS INTERNES DANS LES PAYS DU MARCHÉ COMMUN 161 (1969). Cf., e.g., de Visscher, supra note 22 , at 562 .

100. Fujii v. California, 38 Cal. 2d 718, 722-23, 242 P.2d 617, 620-21 (1952).

101. See Part IIC infra for discussion of these objective tests. For references sec A. BLECKMANN, supra note 2, at 158-59 nn.2-9; Evans, supra note 3, at 74, refers to these objective criteria and nuentions the parties' intent only as a subsidiary criterion in cases where the treaty text is ambiguous.

102. [1928] P.C.I.J., ser. B, No. 15, at 17.

103. See A. BlECKMANN, supra note 2, at 165; A. KolleR, supra note 2, at 97; Sørensen, supra note 25 , at 17-27.

104. 32 U.S. (7 Pet.) 51, 88 (1833). 
on the basis of the intent of the parties as derived from the history of the negotiations, the purpose of the provision, and the Spanish text. Significantly, the Court applied the subjective test only in an affirmative way; it did not consider the proof of intent as a generally necessary prerequisite. ${ }^{105}$

The intent doctrine encounters increasing and well-founded criticism. ${ }^{108}$ For one thing, many parties, in particular those who follow the British method of implementing treaties, lack any intent with respect to the direct application in their country of the norms in question. ${ }^{107}$ Secondly, the intent doctrine serves little practical function today. Intent is usually determined by relying almost exclusively on such objective indicators as the terms, ${ }^{108}$ the context, and the objective purpose of the provision, ${ }^{109}$ or the character of the treaty; ${ }^{.110}$ the actual historical intent as manifested in the legislative history is largely neglected. ${ }^{111}$

Thus, no American courts dealing with articles 55 and 56 have ever even looked at the records of the San Francisco conference. Rather, most have followed Fujii in basing a refusal to apply the human rights clauses on the absence of the "mandatory quality and definiteness which would indicate an intent to create justiciable riglts im private persons immediately upon ratification."112 Rice v. Sioux City Memorial Park Cemetary, Inc., ${ }^{113}$ for example, simply echoes that the Char-

105. But cf. Fujii v. California, 38 Cal. 2d 718, 721, 242 P.2d 617, 620 (1952): "In determining whether a treaty is self-executing courts look to the intent of the signatory parties as manifested by the language of the instrument."

106. E.g., A. BleckManN, supra note 2, at 171-72; A. KolleR, supra note 2, at 100, 103; Riesenfeld, supra note 27, at 550. Wright, supra note 4, does not even mention the subjective test in his discussion of Fujii.

107. See Riesenfeld, supra note 19, at 550. This does not, of course, exclude an intent to create legal norms applicable in countries that do accept treaties as the law of the land. Such an intent might be present, for instance, in the negotiation of bilatcral agreements such as the treaty at stake in United States v. Percheman, 32 U.S. (7 Pet.) 51 (1833).

108. This is the case particularly in the United States. See id.; cf. A. BleCKMANN, supra note 2 , at 160 .

109. Mainly in France. See A. Bleckmann, supra note 2, at 160.

110. See the judgment of the Tax Court of Hamburg of Oct. 29, 1969, reported in 16 Aussenwirtschaftsdienst des Betriebs Beraters 93 (1970), 65 AM. J. INT'L L. 627 (1971). For this objective approach see also Uuited States v. Percheman, 32 U.S. (7 Pet.) 51, 88 (1833) and the Fujii quotation in note 105 supra. The standard formula used by the German Bundesgerichtshof refers to content, purpose, and language as objective indicators of the relevant intent. See, e.g., Judgment of May 24, 1955, 17 BGHZ 309; Judgment of June 21, 1955, 18 BGHZ 22, 25.

111. But cf. United States v. Percheman, 32 U.S. (7 Pet.) 51, 88 (1833), considering the history of the negotiations; Fujii v. California, 38 Cal. 2d 718, 721, 242 P.2d 617, 620 (1952): "[I]f the instrument is uncertain, recourse may be had to the circumstances surrounding its execution."

112. 38 Cal. 2d 718, 724, 242 P.2d 617, 621-22 (1952).

113. 245 Iowa 147, 157-58, 60 N.W.2d 110, 116-17 (1953), aff'd 348 U.S. 880 (equally divided court), vacated on rehearing and cert. dismissed 349 U.S. 70 (1955). 
ter is not intended to supersede existing donestic legislation; Camacho v. Rogers ${ }^{114}$ holds that "the very wording of Article 55 shows that it is not intended to be self-executing." The crucial point in evaluating such reasoning is not the fictitious and superfluous intent, but rather the characteristics of the legal norm as determined by a number of objective criteria. Only a discussion of these criteria nay allow us to speculate on the courts' attitude towards the human rights clauses even where they pretend to apply the objective doctrine of intent.

Even if a court were to attempt to search for the actual historical intent of the drafters of the hunnan rights provisions, its efforts would undoubtedly be futile. Nothing in the documents of the conference indicates that the framers even considered the direct legal impact of the human rights clauses on the doinestic law of the meinbers. ${ }^{115}$ Nor does the Charter itself contain any such explicit indication. Schachter explains this complete absence of evidence by suggesting that the framers meant to leave the doinestic legal methods of carrying out the obligations to the varying constitutional systems of the meinbers. ${ }^{110}$ Accordingly, the historical intent doctrine cannot logically support the conclusion that the human rights clauses are non-self-executing.

In view of its shortcounings and mconsistencies, the intent doctrine should be entirely abandoned except where the intent is explicitly expressed. As long as it is applied, however, the courts will tend to administer varying standards when determining whether a given objective criterion is sufficient evidence of the parties' intent. These standards will also vary in accordance with the scope of the application: ${ }^{117}$ it will probably take stronger evidence of intent to apply the human rights clauses as a basis for raising social and economic rights against the state than it will to apply thein as a standard for the legality of governmental action infringing civil rights. Moreover, international practice indicates that not only the degree of emphasis placed on the intent but also whether intent is relied on at all will largely depend on the nature of the remedy requested-that is, the characteristics of the vindicated human right. The prospect of econormic burdens on the state makes some courts resort to subjective arguments and then fail to find any intent that the provision in question be directly applicable. ${ }^{118}$ On the other hand, using the human rights clauses as the basis

114. 199 F. Supp. 155, 158, 32 I.L.R. 368, 370 (S.D.N.Y. 1961). Cf. Pauling v. McElroy, 164 F. Supp. 390, 393 (D.D.C. 1958) (Charter does not vest plaintiffs with individual rights which they may assert in the court).

115. See Comment, U.N. Charter, supra note 63, at 807; Note, The Declaration of Human Rights, supra note 45, at 1079.

116. Supra note 24 , at 654 .

117. Cf. A. BLECKMANN, supra note 2, at 173 .

118. Cf. id. at 37 (decision of the Austrian Obersten Gerichtshof) and 173. 
of fundamental civil liberties-restricting the freedom of action of public authorities with regard to imdividuals-appears to have a greater chance to pass the scrutiny of the courts without any reference to intent.

\section{The Intent of the Legislature}

Under a dualistic view of the relationship between international and municipal law, the rationale and the criteria for the direct application might be derived from the intent of the legislature, as manifested im the text of the act of incorporation, adoption, or general transformation. Even the actual historical intent as derived from the legislature's record might be a permissible, though by no means exclusive or necessary, guide for the courts. ${ }^{119}$

As discussed above, the countries following the Enghish law, do not appear to have enacted legislation that would imdicate any intent regarding the direct applicability of the liuman rights clauses of the Charter. The same is true of the United States, where the Senate simply gave advice and consent to the ratification. ${ }^{120}$ On the other hand, in most civil law countries the Charter has been incorporated through legislative acts. These acts, though, merely follow the form usually devised to express the consent of the legislature, authorize the executive branch to ratify the treaty, and order the effectuation of the treaty. As a matter of fact, a survey of the formulations used in various countries reveals that the terms of the incorporating acts relate only to the functions of approval, authorization, and giving effect; they do not imdicate any legislative intent or opinion regarding direct application. ${ }^{121}$ To be sure, these acts are generally considered in theory to effectuate the incorporation or transformation of the treaty, but they do not determine which of the incorporated norms of the treaty shall be self-executing:;22 the formulas are uniformly used in the respective countries regardless of the specific content and nature of the treaty.

Formulations specifically indicating the legislature's recognition of

119. For comprehensive analysis and evaluation of this approach see A. BLECKMANN, supra note 2, at 182-227.

120. Act of July 28, 1945, 59 Stat. 1031. The United Nations Participation Act of 1945,22 U.S.C. $\$ \S 287-287$ (e) (1970), does not deal with human rights questions nor with the internal effects of the Charter in general.

121. A. BLECKMANN, supra note 2, at 186 et seq. The Austrian approval of the Charter, for instance, contains the traditional formula. Law of Oct. 18, 1956, [1957] BGB1.965.

122. An exceptional regulation in the Austrian Constitution authorizes the legislature to provide in the act of approval (Zustimmungsgesetz) that the treaty needs special legislative implenientation. See A. BlecKManN, supra note 2, at 34-35, 183-84 $\&$ n.5, 190. As this provision is not retroactive, no conclusions may be drawn as to the effects of the Austrian ratification of the Charter in 1955. 
the self-executing nature of a given treaty are rare exceptions, occurring mainly in cases of predominantly law-making treaties. ${ }^{123}$ One can assume that because the Charter is a constitutional document and has a very limited number of potentially self-executing provisions, national legislatures have not indicated their intent or opinion on whether or not it is self-executing. Similarly, while a number of executive orders and other non-statutory measures may be said to indicate the applicability of Charter provisions on the legal status, privileges, and immunities of the organization, ${ }^{124}$ there are, to my knowledge, no such measures regarding the human rights clauses. Finally, it is difficult to find any relevant indication of legislative intent in the mere fact of official publication of the treaty, due to the widespread practice of publishing treaties regardless of their nature and content. ${ }^{125}$ Hence, the resort to the legislature's intent, while in theory a valid device, does not appear to provide any argument in favor of or against the self-executing nature of the human rights clauses. This question can only be answered by means of the remaining objective tests.

\section{Other Objective Tests of Self-Execution}

\section{The Doctrine of Political Treaties}

Judicial practice and doctrine of almost all states consider certain treaties whose purpose and substance is generally outside the sphere of national law as non-self-executing because of their political nature. ${ }^{120}$ This category is said to include treaties that create obligations for signatories only on the international level. Treaties involving international loans and the supply of armaments, ${ }^{127}$ as well as treaties sucl as those of alliance, neutrality, assistance, and peace that regulate the political relations between the subjects of international law are good exainples of political treaties. ${ }^{128}$ The constitutions of public international organizations such as the United Nations are often said to regulate political relations and therefore to be political treaties. ${ }^{129}$

While the classification of the United Nations Charter as a whole as political is correct in principle, it does not support a case agamst the

123. For details see A. BLECKMANN, supra note 2, at 190-94.

124. Arts. 104 and 105; cf. Schlüter, supra note 16, at 34-36. See also the French Decree of April 26, 1947, concerning the Execution of the Convention on the Privileges and Immunities of the United Nations, [1947] J.O. 4462, [1947] J.C.P. III No. 12190.

125. Cf. A. BleckmanN, supra note 2, at 194-95. The United States is one of the few countries where publication is not needed for internal application. S $\phi$ rensen, supra note 25 , at 15 .

126. Cf. Sørensen, supra note 25 , at 22.

127. In the language of Foster v. Neilson, 27 U.S. (2 Pet.) 253, 314 (1829): "[T] he terms of the stipulation import a contract."

128. For references see A. BLECKMANN, supra note 2, at 262-63.

129. E.g., id. at 250. 
self-executing nature of the human rights provisions. The real problem is the applicability of the individual treaty provision; this question is not finally disposed of by the nature of the treaty as a whole. ${ }^{130}$ Accordingly, the self-executing nature of articles 104 and 105 has been widely recognized notwithstanding the political nature of the Charter as a whole. ${ }^{131}$ The crucial question is whether the luunan rights clauses are political and thus cannot be applied by the courts.

The criteria for whether a treaty provision is political vary from state to state, since the concept of political treaties is based on a variety of rationales reflecting differences in the structures of internal legal orders. Above all, the well-known doctrines of political questions (United States) and acte de gouvernement (France) have had some impact on the doctrine of self-executing treaties. ${ }^{132}$

Wright even contends that in American constitutional law, the question of whether a treaty provision is self-executing is only an aspect of the political question doctrime. ${ }^{133}$ The controlling rationale of both, he continues, is the preservation of the constitutional rights of the political organs of the federal government in matters which have been considered peculiarly within their competence. ${ }^{134} \mathrm{He}$ concludes that the doctrine does not provide any argument against the application of the human rights clauses in preference to conflicting state legislation. ${ }^{135}$ But whether the doctrine also allows the application in preference to prior conflicting federal legislation is a separate question, and one which again imdicates the potential impact of the circumstances of the application upon the self-executing character of the provisions. The preservation of the federal legislature's constitutional rights should end where the treaty contains clearly justiciable norms-that is, sufficiently concrete rules which for historical or practical reasons are not considered within the exclusive competence of the legislature. Norins regarding the proinotion of human rights have never been considered exclusively legislative. ${ }^{130}$ Indeed, the American courts that refused to apply the human rights clauses never did so because of the doctrines of political questions or political treaties. ${ }^{137}$

The practice in many civil law countries of legislative approval of

130. Sørensen, supra note 25, at 24.

131. See, e.g., Curran v. City of New York, 191 Misc. 229, 234, 77 N.Y.S.2d 206, 212 (Sup. Ct. 1947).

132. For a more detailed discussion of the various concepts see A. BLECKMANN, supra note 2 , at 265-87.

133. Supra note 4, at 64-66, referring to Foster v. Neilson, 27 U.S. (2 Pet.) 253 (1829).

134. Id. at 68; cf. Evans, supra note 3, at 75.

135. Wright, supra note 4 , at 69 , with respect to Fujii.

136. Id. at 68.

137. See cases cited note 91 , supra. 
treaties in the form of acts secures sufficient political participation and control to make the rationale of the concept of political treaties in those countries slightly different. In such countries, the general concept of internal sovereignty, which tends to preserve the freedom of internal action of the government and the legislature at the expense of the courts and individuals, is emphasized. ${ }^{138}$ Still another widely reeognized concept is the courts' limited competence to make rational policy decisions. ${ }^{139}$ Ideas of democratic representation, organizational competence, and rule of law are controlling here. Again, these rationales do not justify considering the human rights clauses non-self-executing as a whole since, as the above analysis shows, the clauses clearly go beyond inere regulation of the political relations of United Nation members. Rather, they create certain legal obligations in regard to the states' behavior on both the international and national levels. In other words, since they deal with the relations between public authorities and individuals, their purpose and substance is not outside the sphere of national law.

Courts therefore should not reject direct application on the sole grounds of the alleged political nature of the clauses. ${ }^{140}$ Their application by national courts neither interferes with the political relationship of the state to other countries nor necessarily involves policy decisions that have traditionally been left to the political organs of government; nothing in the nature of the international human rights obligations requires their execution exclusively by political organs on the international or national level. On the contrary, the effective protection of human rights may be regarded as one of the traditional prerogatives of the national judiciary. The real problem in finding the human rights clauses self-executing is thus not the nature of the provisions but their relative vagueness, which might require the legislature to provide implementing norms for the courts to apply.

\section{Constitutional Limitations}

In a few countries, in particular the United States and Mexico, ${ }^{141}$ the constitution and the doctrine of pohtical questions have given rise to a well-established principle that certain categories of treaties are never self-executing because their execution falls within the exclusive constitutional competence of the legislature. Among these categories, ${ }^{142}$ only one is of particular interest here: treaties requiring ap-

138. Cf. A. BLECKMANN, supra note 2, at 265-67.

139. Id. at 268-69, with special reference to the United States situation.

140. "Political" in this context refers to the content of the treaty rather than to its addressees, i.e., the political organs of government.

141. See Evans, supra note 2, at $204 \&$ n.8.

142. For details see Evans, $i d$. at 185; Evans, supra note 3, at 69; Wright, supra 
propriations. In these countries the application of the human rights clauses by the courts would therefore be necessarily limited to cases where no congressional appropriation is required. Thus, whenever the enforcement of human rights would impose financial burdens on the government, as may be the case with some social and economic rights, the courts in these countries are forbidden to apply the clauses without congressional intervention. ${ }^{143}$ Similar results will be reached in other countries on the basis of different doctrinal principles which will be discussed later.

\section{The Subject Matter}

Courts and legal writers in some countries have tried to establish on an empirical basis some relationship between the subject matter of a treaty and its application. Certain categories of treaties, such as those concerning nationality, minorities, foreigners, and human rights, are said to be generally self-executing. ${ }^{144}$ This categorization is, of course, of very little value, simce the relevant issue is not the subject matter of the treaty as a whole but rather that of the individual provision in question. Hence, the widespread recognition of the self-executing nature of the European Convention on Human Rights ${ }^{145}$ and the non-operative United Nations Covenant on Civil and Political Rights does not directly bear on whether the human rights clauses of the Charter are self-executing. However, some courts may conceivably derive froin the international efforts to create self-executing human rights provisions a presumption in favor of the applicability of the Charter clauses.

\section{International Execution and Implementation}

Treaty norms providing for further international executory measures are considered non-self-executing in some countries-Germany, the Netherlands, and France, for example. ${ }^{146}$ Yet, one should recall

note 4, at 68; Wright, supra note 92, at 3-4; cf. Note, The Declaration of Human Rights, supra note 35 , at 1087.

143. See Wright, supra note 4, at 77.

144. Cf. A. BleCKMANN, supra note 2, at 304; A. Koller, supra note 2, at 97; Evans, supra note 2, at 186; Evans, supra note 3, at 69, 73-74; Knapp, Les particuliers et les traités internationaux devant les tribunaux internes, 88 ZEIrsCHRIFT FÜR SCHWEIZERISCHES RECET 259, 277-95 (1969).

145. See generally A. DEL Russo, supra note 14, at 202 et seq.; Buergenthal, supra note 13 at $76-77$.

146. See A. BleckmanN, supra note 2, at $304 \&$ n.231. The German Reichsgericht, for instance, stated that "content, purpose and tenor of the specific provision [must be] so adapted as to exercise an effect in private law without the necessity of further international or national action." Judgment of Mar. 29, 1928, 121 RGZ 7, 9 (emphasis added). 
in this connection that article 56 as construed above provides for both international and separate, internal action. Moreover, while the framers at San Francisco did contemplate impleinentation of the clauses through a multilateral convention, this does not necessarily mean that the clauses should not be directly applied. ${ }^{147}$ In particular, it does not indicate any intent of the parties to exclude direct application. Nor may any inference be drawn from current efforts to protect human rights through the United Nations Covenants. ${ }^{148}$ These efforts indicate at most the limitations and uncertainties of the Charter provisions rather than their total mapplicability. Finally, the literature and practice regarding articles 104 and 105 support the conclusion that the huinan rights provisions may be directly applicable even though further international implenientation was contemplated. Articles 104 and 105 have been held self-executing although they were designed to be, and were in fact, implemented by the General Convention on Privileges and Immunities. ${ }^{149}$

Furthermore, as Quincy Wright has argued, the United Nations has no exclusive coinpetence in the implementation of human rights; the meinbers are free to follow their normal constitutional practices with regard to the execution of the Charter. ${ }^{150}$ Hence, nothing in articles 55 and 56 prevents the courts from applying these clauses to the extent allowed under the remaining tests.

\section{States as Formal Addressees of the Legal Norm}

Some European legal writers inaintain that treaty provisions, even if they concern individual interests, are not self-executing if their terms explicitly refer to the parties of the treaty. ${ }^{151}$ Such reference is made in article 56, where the "[in]embers pledge themselves" to take certain actions. However, the only logical basis for the above contention is the premise that explicit language providing for the application is necessary. As explained above, this approach would be contrary to the common practice. Reference to the states may be intended to place some emphasis on the legal obligation of the members to promote huinan rights; it does not, as such, imdicate any intent to prevent whatever organ the state nray designate for the purpose from executing this obli-

147. See Schachter, supra note 24 , at 654 .

148. See H. GuRADZE, supra note 46, at 113, 117. But cf. Preuss, supra note 27, at 295 .

149. Convention on the Privileges and Immunities of the United Nations, opened for signature Feb. 13, 1946, 1 U.N.T.S. 15. For adoption of the Convention in the United States, see 22 U.S.C. $\$ 288$.

150. Wright, supra note 4 , at 74-75.

151. For references see A. BleckmanN, supra note 2, at 287 n.180; P. GugoenHEIM, supra note 64 , at 34 . 
gation, and no such intent was expressed at the conference in San Francisco.

Accordingly, most legal writers and courts do not attach any decisive importance to the formal addressee of the provision. They try to determine the real addressee through interpretation and application of the remaining tests. ${ }^{152}$ As construed above, articles 55 and 56 impose upon the states an obligation to achieve respect for and observance of human rights. Since luman rights are primarily directed against the state, this can only mean that the state is internationally obligated to make sure that its own organs observe the human rights implicitly prescribed by the Charter. To be sure, this may require action on all internal levels; but in view of the openness of the text, the state may rather have been left free to designate the organs competent to execute the international obligation. The very wording of "to take action to achieve" might be construed to permit such discretion on the part of the members. ${ }^{153}$ In other words, the language of articles 55 and 56 may not force either the legislature or the courts and administrative agencies to respect and observe human rights.

On the other hand, it is clear that this construction would endanger the fulfillment of the international obligations. A teleological, effective interpretation should, therefore, lead to the opposite result, notwithstanding the formulation of the clauses as state obligations. Accordingly, the legislature as well as judicial and administrative agencies or individuals may be considered as the real addressees, depending on whether the provision is concrete enough to be enforced without legislative elucidation by the courts or to create individual rights. This interpretation is clearly the result of a methodological decision based on the value judgment that increased protection of human rights is generally desirable. Whether the courts will endorse this policy is an open question.

\section{The Legislature as the Eventual Addressee}

Having argued that the human rights clauses may in primciple address themselves to internal state organs, I turn to the question whether the duty to take separate action must be construed as a duty merely to legislate on the field of human rights. If so, the human rights clauses will be non-self-executing under a widely accepted doctrine.

In the United States, inany commentators maintain that a treaty may not be enforced by the courts when its terms explicitly require

152. A. Koller, supra note 2 , at 101,108 \& n.80 (court decisions); cf. A. BLECKMANN, supra note 2, at 287-90; 1 W. WENGLER, VöLKERRECHT 237 (1964).

153. Cf. Stettinus, Report to the President, 12 Dep't STATE Bull. 929 (1945). See also P. DRost, supra note 35, at 29. 
congressional implementation, ${ }^{154}$ when it addresses itself only to the political rather than the judicial sphere, ${ }^{155}$ or when it specifies a particular organ or procedure for its execution. ${ }^{156}$ These statements reflect the language of Foster $v$. Neilson: "[W] hen either of the parties engages to perform a particular act, the treaty addresses itself to the political not the judicial department." ${ }^{.157}$ A similar view is expressed by a number of courts and legal writers in European countries. ${ }^{168}$

"Separate action to achieve respect for, and observance of, human rights" in its ordimary meaning appears to imclude action taken by any branch of government. There is no reason to construe this language as an exclusive reference to the legislature. To be sure, "separate action" may require the state to enact laws-for example, laws creating substantive rules, procedures, and regulatory or operative agencies necessary to give practical effect to human rights and particularly social and economic rights. ${ }^{159}$ It may also include an obligation of the legislature to review and repeal laws impairing human rights. But it is doubtful that this potential involvement of the legislature forces the courts to give effect to laws grossly violating human rights and thus to impair those rights, notwithstanding the state's international obligation to promote respect for, and observance of human rights. The language of Fujii indicates that the California Supreme Court thinks it does, ${ }^{100}$ but this result is inconsistent with the principle of construction in good faith. ${ }^{161}$

Moreover, various national doctrines link the problem of the explicit legislative addressee to the question of vagueness: they recognize an exclusive executory competence of the legislature only in so far as the nornis leave discretion to the legislature and cannot be rendered inore specific by judicial interpretation. ${ }^{162}$ Both this notion and the above construction of "separate action" support the conclusion that the human rights clauses, once incorporated in the domestic law, address

154. Evans, supra note 2, at 185; Evans; supra note 3, at 68; Note, The Declaration of Human Rights, supra note 35, at 1078.

155. Hudson, supra note 35 , at 545 .

156. Wright, supra note 4, at 69.

157. 27 U.S. (2 Pet.) 253, 314 (1829).

158. For references see A. BLECKMANN, supra note 2, at 290-91 nn.184-97; A. KOLLER, supra note 2, at 104 n.72. See also note 146, supra.

159. See Wright, supra note 4, at 77. See also P. Drost, supra note 35, at 29.

160. 38 Cal. 2d 718, 722, 242 P.2d 617, 621 (1952): "Although the member nations have obligated themselves to cooperate with the international organization in promoting respect for, and observance of, human rights, it is plain that it was contemplated that future legislative action . . . would be required to accomplish the declared objectives ...." (emplrasis added).

161. Vienna Convention, supra note 42, art. 31, para. 1.

162. Cf. A. BLECKMANN, supra note 2, at 294-99; Schachter, supra note 24, at 656. 
themselves not only to the legislature but also to the courts, at least in so far as they contain sufficiently precise norms.

\section{Legal Norms}

Earlier in this study, I pointed out that articles 55 and 56 inust be considered international legal norms; while this status may provide a presumption in favor of regarding thein as legal norms within the domestic spliere, courts may nonetheless apply their own criteria in determining the scope and form of application. Many authorities insist that whatever criteria are used, it inust be determined that a particular treaty provision is a domestic legal norm before it can be directly applied. Thus, in the United States, as early as 1829, Foster v. Neilson referred to the need for a self-executing provision to be "a rule for the Court."103 Since that time, this primciple has been generally recognized, though in various formulations. ${ }^{164}$ Similar views have been expressed by numerous European authors. ${ }^{165}$

However, concrete criteria for the existence of a legal norm binding upon the courts have not been developed in cases concerning selfexecuting treaties. ${ }^{106}$ The only criterion mentioned by American authorities is the degree of precision. ${ }^{167}$ This problem, whicl is not part of the traditional norm theory, will be discussed separately.

Other norm criteria have been developed, particularly in civil law countries. The most important concern the concept of generality: the provision must be general with respect to its orgin, its addressees, and its content. The first requirement-that a norm must originate with a legitimate government organ-is either neglected in the context of treaty application or said to be inet by legislative approval of the treaty. The second is colmected with the addressee problem, ${ }^{168}$ as previously discussed, the liuman rights clauses may reasonably be said to address themselves, if to anybody, to all state organs and individuals, rather than to certain organs or individuals. As far as the third requirement is concerned, there can be no doubt that the liuman rights clauses as construed above constitute an abstract regulation of an uncertain number of future situations and thus are general in content.

163. 27 U.S. (2 Pet.) 253, 314 (1829).

164, E.g., Evans, supra note 3, at 68: "A self-executing treaty is one which furnishes by its own terms ... a rule of law for the executive branch of the Government, the courts, the States, or for private individuals;" Schachter, supra note 24, at 654; Wright, supra note 92, at 6 . The Fujii case refers to a "rule that, standing alone, would be enforceable in the courts." 38 Cal. 2d 718, 722, 242 P.2d 617, 620 (1952).

165. For details see A. BleCKMANN, supra note 2, at 244-45.

166. See id. at 246.

167. E.g., Schachter, supra note 24, at 646 ; Wright, supra note 92, at 6.

168. See part $\mathrm{IIC}(5)$ and (6). 
In practice, the courts are unlikely to apply these doctrinal concepts to the human rights clauses. This is due in part to the general tendency to formalize the concept of "norm" and to apply as a rule of law every provision that has either been enacted or approved by the legislature.

\section{Precision}

The review of the previous tests has at various points brought out the importance of sufficient precision. The relative vagueness of the human rights provisions has necessitated interpretive efforts to determine whether they create legal obligations concerning the domestic sphere and binding upon internal state organs, including the courts. Unless sufficiently concrete legal norms can be derived froin articles 55 and 56 , courts will not be bound to apply these provisions.

Legal doctrine in inost countries attaches considerable importance to the concept of precision. As early as 1829, Chief Justice Marshall wrote in Foster v. Neilson that a treaty provision is "to be regarded in courts of justice as equivalent to an act of the legislature, whenever it operates of itself without the aid of any legislative provision."100 According to one commentator, this suggests that under Umited States constitutional law "the terms of a treaty inust be very precisely drafted if they are to be relied on . . . as being capable of operating ex proprio vigore." 70 In fact, various American decisions have relied on Marshall's opinion and required that the treaty provide standards sufficiently detailed for executive-administrative application, ${ }^{171}$ treating precision either as an independent criterion or as an indicator of the parties' intent to create justiciable norms. ${ }^{172}$

Alleged vagueness has been the decisive reason, for example, for the Califorma Supreine Court's refusal to apply articles 55 and 56. The pertinent part of the Fujii decision claims that "when the framers of the charter intended to make certain provisions effective without the aid of implesnenting legislation they einployed language which is clear and definite and manifests that intention."173 Fujii went on to find that although articles 104 and 105 meet this test, the human rights clauses do not:

The provisions in the charter pledging cooperation in promoting observance of fundamental freedoms lack the inandatory quality and

169. 27 U.S. (2 Pet.) 253, 314 (1829).

170. Evans, supra note 3, at 74.

171. See cases cited by McLaughlin, supra note 99, at 748 .

172. See generally Schachter, supra note 24, at 646, 655-57.

173. 38 Cal. 2d at 723, 242 P.2d at 621 (1952). 
definiteness which would indicate an intent to create justiciable rights

in private persons immediately upon ratification. ${ }^{174}$

The same rationale seems to underlie Camacho v. Rogers, ${ }^{175}$ the other decisions which merely echo Fujiii ${ }^{178}$ and especially Vlissidis v. Anadell, a case concerning the allegedly discriminating immigration quota system in which the court failed to find any "section of the United Nations Charter which purports to regulate the immigration policies of member nations." $" 177$

Courts and jurists in many countries, particularly in Europe, have applied the domestic standards of precision to treaties other than the Charter. ${ }^{178}$ These requirements vary from country to country, reflecting the structure of the respective legal orders. Two inain rationales seem to be controlling. The first is the separation of powers, restricting the courts' power to make rules of law at the expense of the legislature. This primciple tends generally to limit the applicability of imprecise norms, since their execution would require policy decisions traditionally left to the legislature.

The second rationale involves the concept of fair notice [Rechtstaatlichkeit, Rechtssicherheit], derived from either the rule of law primciple generally or due process particularly. Standards must be precise enough, it is posited, to clearly inform the individual of how he is expected to behave. ${ }^{170}$ Obviously, the fair notice primciple is mainly pertinent to the imposition of obligations upon the individual. Since human rights are usually obligations of public authorities, the fair notice primciple is probably not a sufficient basis for denying the selfexecuting nature of the human rights clauses. Thus, whether a treaty provision is considered precise enough to be self-executing may depend on which of the two rationales for the precision requirement the courts adopt.

The human rights clauses will probably have to meet the same precision requirements as national norms concerning human rights. ${ }^{180}$ In the United States, therefore, the very permissive precision standards implicitly controlling the application of the equal protection and due process clauses of the Constitution may conceivably guide the courts in dealing with the human rights provisions. ${ }^{181}$

174. Id. at 724-5, 242 P.2d at 622 .

175. 199 F. Supp. 155, 158, 32 I.L.R. 368, 370 (S.D.N.Y. 1961): "Indeed the very wording of Article 55 shows that it is not intended to be self-executing."

176. Cases cited in notes 113 and 114 supra.

177. 262 F.2d 398, 400, 28 I.L.R. 463, 463 (7th Cir. 1959).

178. Cf. A. BlECKMANN, supra note 2, at 305-21; A. Koller, supra note 2, at 71-72.

179. For details see, e.g., A. BLECKMANN, supra note 2, at 311.

180. Cf. id. at 312, 319.

181. See Schachter, supra note 24 , at 655 and n.63. 
In practice, however, many courts require in certain instances that treaties meet precision standards more stringent than those applied to national norms-where the treaty provision fails to fit harmoniously into the general structure of the legal order, for example, or where it is opposed to an elaborate systen ticular area. ${ }^{182}$ For example, the Austrian constitutional court refused to apply the procedural safeguards of article 6 of the European Convention on Human Rights on the grounds that they are relatively vague in comparison with the elaborate Austrian procedural system in both civil and criminal law. ${ }^{183}$ While this particular approach is not uniformly sliared by other European courts, ${ }^{184}$ it nevertheless represents a general reluctance of the courts to allow treaty norms to revolutionize the doinestic legal order. ${ }^{185}$ Thus, the less developed the protection of fundamental rights is in a given country, the more likely the courts may be to find the human rights provisions insufficiently precise. One may speculate, for example, that economic and social rights, in view of their enibryonic stage of development in Western countries will be more likely than traditionally accepted civil riglts to be denied enforcement on the ground that the human rights clauses are too vague. ${ }^{186}$ The opposite attitude may be expected in socialist countries. ${ }^{187}$

Claiming social and economic rights on the basis of the human rights clauses is likely to raise vagueness objections for another reason: by their very nature, ${ }^{188}$ sonie such rights may require both fundamental changes of the socio-economic structure and new, specific procedures. Since the pertinent Cliarter provisions liardly prescribe these

182. See A. BLECKMANN, supra note 2 , at $313,316$.

183. Judgment of June 27, 1960, 83 Juristische Blätter 352, 353 (Austrian Constitutional Court 1961).

184. See the survey by Buergenthal, supra note 13.

185. Cf. A. BLECKMANN, supra note 2, at 316-17.

186. Schachter observes that the "concept of human rights and fundamental freedoms are closely akin to the basic rights and freedoms which American courts have traditionally been required to define ... for the purpose of determining the scope of constitutional protection." Schachter, supra note 24 , at 655 \& n. 64 .

187. The social and economic rights in the International Bill of Rights are largely the result of the efforts of the socialist countries. See Scupin, Utber die Menschenrechte, in GEGENWARTSPROBLEME DES INTERNATIONALEN RECHTS UND DER RECHTSPHILOSOPHIE, FESTSCHRIFT FÜR RUDOLF LAUN 173, 175 (1953).

The Russian Constitution of 1936 recognizes a number of social rights. For socialist views on human rights see, e.g., Berman, Human Rights in the Soviet Union, 11 How. L.J. 333 (1965); Nedbailo, Human Rights and Action to Combat Racism, OвJECTIVE: Justice, Vol, 3 No. 3, at 26 (1971); Panczuk, Human Rights and the Soviet Union, 10 WORLD JUSTICE 224 (1968); Przetacznik, The Socialist Concept of Protection of Human Rights, 38 Social RESEARCH 337 (1971).

See also Evatt, Economic Rights in the United Nations Charter, AnNals 4-5 (1946), recalling Australia's role in the drafting of the pertinent Charter provisions.

188. These rights correspond to state obligations to perform. 
policy changes and procedures, the provisions will almost certainly be considered vague norms needing legislative impleinentation. ${ }^{189}$

Obviously, the vagueness principle is a legal tool allowing the states to preserve their own freedom to act at the expense of individuals. Since it endangers the fulfillment of the obligations undertaken in article 56 and tends instead to maintain the status quo, it should be decreasingly relied on by the courts, especially where the legislature deliberately fails to execute the obligations. The question then becomes whether it is in fact possible to make the human rights clauses concrete enough to pass precision criteria. Any norm is necessarily vague to a certain extent and therefore requires interpretation. Although interpretation is a fundamental function of the courts, it is traditionally limited to a certain set of methods; these methods do not exclude value judgments. Beyond the limited purview of judicial interpretive methods extends the area of execution or impleinentation generally reserved to other branclies of government. The line between the two functions cannot, of course, be drawn strictly and varies froin country to country. These commonplaces should be borne in mind because some interpretations of the Charter provisions appear to depart to a certain extent from generally accepted methods. While these approaches and their results may be desirable as a inatter of policy, they run the risk of being rejected by the many orthodox lawyers who tend to limit the role of the judiciary.

The first issue is how to construe the words "human rights and fundamental freedoms." To be sure, finding a workable, abstract defimition of this term would not be difficult. It is more troublesome to establish a catalogue of the specific human rights that the courts are to enforce.

A inerely literal construction of the words "human rights" is obviously useless. While recourse to the legal context may be used to interpret thein, there is no agreenent relating to the human rights clauses made between all the parties in cormection with the acceptance of the

189. See Wright, supra note 4 , at 77.

The factual and legal problems involved in the implementation of these sorts of rights are recognized in the Covenant on Economic, Social and Cultural Rights. Its provisions are, in contrast to those in the Covenant on Civil and Political Rights, drafted as mere state obligations. In addition, art. 2, para. 1 provides:

Each State Party to the present Covenant undertakes to take steps, individually and through international assistance and co-operation, especially economic and technical, to the maximum of its available resources, with a view to achieving progressively the full realization of the rights recognized in the present Covenant by all appropriate means, including partieularly the adoption of legislative measures.

It is simply unreakistic to expect that the courts in applying the Charter provisions will go far beyond the cautious program of the Covenant and impose obligations involving the commitment of substantial resources. 
Charter; nor is there any instrument made by one or more parties and accepted by the others. ${ }^{190}$ Only the International Bill of Human Rights and the customary international law of human rights, therefore, promise any aid in interpreting the human rights provisions.

An orthodox approach would deny any direct impact to the Covenants because they are not yet operative. When in effect, though, they will probably be a legitimate interpretive device, for they could be construed as a subsequent agreement between the parties regarding the interpretation of the Charter or the application of the human rights provisions. ${ }^{191}$

The interpretive role of the Umiversal Declaration has been subject to a well-known, widespread controversy. Considering the Declaration an authoritative interpretation of the Charter by the General Assembly is one theoretical approach used to argue that the Universal Declaration is legally binding. ${ }^{192}$ Most commentators have rejected this approach either by pointing to the language of the Declaration and the circumstances surrounding its adoption ${ }^{193}$ or by analyzing the theoretical problems with considering General Assembly resolutions "authoritative interpretations." 194 Recently, emphasis has shifted from the formal interpretive powers of the General Assembly to the significance of the collective behavior of states as expressed in the unanimous adoption of resolutions and, particularly, in the adoption of the Universal Dec-

190. See Vienna Convention, art. 31, paras. 2(a), (b).

191. See id. art. 31, para. 3(a) and the preambles of the U.N. Covenants.

192. This has been the view of a small minority of delegates to the General Assembly and of a number of legal writers. Cf. M. GANJI, supra note 63, at 161-66: H. GURADZE, supra note 46 , at 127-29. Unfortunately, they confine themselves to dogmatic affirmation rather than giving rational and theoretically valid reasons. See, e.g., REPORT, supra note 92, at 5; Wright, supra note 4, at 71.

The Montreal Statement mentioned in Sohn, Machinery, supra note 92, asserts that the "Universal Declaration of Human Rights constitutes an authoritative interpretation of the Charter of the highest order, and has over the years become a part of customary international law." (Emphasis added). For additional references see J. CAREY, supra note 11, at 12-14 \& nn.19-21; Newman, supra note 32, at 285 n.7.

193. M. GANJI, supra note 63 , at 161-66; H. LAUTERPACHT, supra note 27 , at 397-408; Note, The Declaration of Human Rights, supra note 35, at 1069-73; Hudson, supra note 35, at 546; Kunz, Declaration, supra note 33, at 321-22; Kunz, International Protection, supra note 33, at 116; cf. Schwelb, supra note 6, at 218.

194. Thus, Kelsen maintains that an authoritative interpretation is possible only by an amendment to the Charter. H. KELSEN, supra note 36, at 40. Lauterpacht rejects the concept of an authoritative interpretation on the premise that the General Assembly cannot impose specific legal obligations upon the members by extensive interpretation of the general obligation under the Charter. H. LAUTERPACHT, supra note 27, at 403-09. For a critical comnent on this view see H. GuRADZE, supra note 46, at 129-30. Both Kelsen and Lauterpacht seem implicitly to deny to the General Assembly what would amount to a formal law-making function by the back door through Charter interpretation. 
laration. ${ }^{195}$ Commentators now see such unanimous adoption, and later resolutions implementing the provisions thus adopted, either as a reflection of general principles of law recognized by civilized nations or as constituting international custom for the purpose of showing a general practice accepted as law. ${ }^{196}$ However, few authors in the field of human rights have bothered to go beyond mere affirmation that the Universal Declaration has becoine a part of international customary law; ${ }^{197}$ the traditional doctrine defining the constituent elements of customary law is rarely applied in detail. ${ }^{198}$ It is impossible here to determine conclusively to what extent the human rights set forth in the Universal Declaration have become part of general imternational law. It should be noted, however, that there is considerable evidence of international custom concerning several fundamental human rights, which might indicate a general practice accepted as law. ${ }^{199}$

One other doctrinal approach to the legal effect of the Universal Declaration ought to be mentioned: that the Declaration has acquired an authority that at least takes it out of the category of non-binding pronouncements, ${ }^{200}$ even if it is not clearly binding. However, national courts will almost certainly accept as a guide to interpretation only international norms whose nature as a source of $l_{a w^{201}}$ is beyond any doubt.

A more promising method of using the Covenants and the Universal Declaration as an aid to interpreting the human rights provi-

195. For the new approaches to the law-making role of the General Assembly, see the important contributions cited by Bleicher, The Legal Significance of Re-Citation of General Assembly Resolutions, 63 AM. J. INT'L L. 444 n.1 \& 2 (1969).

196. See I.C.J. STAT. art. 38.

197. See, e.g., the quotation from the Montreal Statement, note 192 supra; Humphrey, The U.N. Charter and the Universal Declaration of Human Rights, in The International Protection of Human Rights 39, 53 (E. Luard ed. 1967).

For a more careful approach see Bleicher, supra note 195, at 444-78, especially 458-65.

198. But see Guradze, Are Human Rights Resolutions of the U.N. General Assembly Law-Making?, 4 Human Rights J. 453-61 (1971). Guradze denies the obligatory character of the Declaration on the traditional grounds that the voting in the General Assembly cannot be considered as law-creating state behavior accompanied by any opinio iuris sive necessitatis.

For new analyses replacing the latter element with such concepts as "reasonable community expectations," see Bleicher, supra note 195, at 477; Higgins, The United Nations and Lawmaking: The Political Organs, 1970 A.S.I.L. Proceedings 37, 45.

199. See the surveys of international practice cited note 6 supra. A number of courts have referred to the Declaration as evidence of generally accepted principles of law or of customary international law. See cases cited notes 271-273 infra. See generally J. BrownLIE, supra note 77, at 463 and $\mathbf{n . 2}$ and Barcelona Traction case, [1970] I.C.J. 3, 32, paras. 33-34.

200. See the interesting study by E. SchWELB, HUMAN Righrs AND THE INTERNATIONAL COMMUNITY 73, 74 (1964).

201. See I.C.J. StaT. art. 38. 
sions of the Charter is therefore by examining the extent to which they have been incorporated into or are evidence of international customary law. ${ }^{202}$ When doing so, courts may arrive at different conclusions regarding the scope of this imcorporation. Moreover, they may derive general principles of international law from the uniform attitude of national legal orders on a central minimum of human rights, imcluding the right to life and liberty, freedom of rehigion, and nondiscrimination. ${ }^{203}$

Yet, while the International Bill of Human Rights is of utmost importance for the interpretation of the international obligations of the states, ${ }^{204}$ the foregoing analysis shows that national courts still often refuse to apply directly all its provisions, even when they are claimed to be incorporated in the Charter's concept of liuman rights. This is particularly true in decisions concerning social and economic rights, as discussed above; ${ }^{205}$ their definition in the Declaration and the Covenants may still be considered too vague for direct application.

Still, reference to the International Bill of Human Rights as imcorporated im general international law and reflecting a common imterpretive practice of the parties ${ }^{206}$ appears to be a promising approach to the imterpretation and application of the Charter clauses. While the courts' task would be facilitated considerably by a more detailed and comprehensive analysis of the present state of the general imternational law of human rights, nothing requires the courts to take an all or nothing position in regard to the applicability of the human rights clauses. ${ }^{207}$ On the contrary, whenever they can render the clauses more specific using accepted methods of interpretation they are bound to carry out the duty to respect and observe human rights. Whereas interpretive recourse to general international law is necessary for the determination of particular human rights, no such procedure seems to be required in cases involving discrimination infringing upon human rights, for example, since the nondiscrimination principle contained im

202. Cf. Waldock, supra note 74 , at 199: "[W]e may refer to [the Declaration] for indications of the content of the human rights envisaged in the Charter." See generally Newman, supra note 32 , at 285-88.

203. See generally M. GANJI, supra note 63 , at 123-31. These rights are contained in the constitutions of over 75 states. Id. at 130-31.

204. A similar impact on the interpretation of the clauses may be ascribed to other international instruments such as the Convention on the Prevention and Punishment of the Crime of Genocide, the Convention on the Elimination of All Forms of Racial Discrimination, the Slavery Conventions, the Convention on the Political Rights of Women, the Convention Relating to the Status of Refugees, and the Convention Relating to the Status of Stateless Persons; see Newman, supra note 32, at 288-89.

205. See text accompanying notes 186-89 supra.

206. See Vienna Convention, art. 31, para. 3(b).

207. See Schachter, supra note 24 , at 656 (referring to the supremacy clause of the U.S. Constitution). 
article 55 and in several other provisions of the Charter ${ }^{208}$ is a fairly definite rule of law. ${ }^{209}$ Once it is established that action by public authorities affects human rights, any discrimination on the basis of race, sex, language or religion is prohibited unless based on legislation that, for particular reasons, is not superseded by the Charter. ${ }^{210}$

To be sure, the language of article 55 suggests that only discrimination affecting "human rights and fundamental freedoms" is prohibited. Hence, discrimination affecting other interests-access to such public facilities as libraries and swimming pools, for instance-is seemingly not governed by the Charter. The right to nondiscrimination, however, can reasonably be considered a fundamental human right that is itself recognized under international customary law ${ }^{211}$ and the vast majority of national constitutions. ${ }^{212}$ This prohibition against discrimination has been further expanded by the International Bill of Human Rights, which may guide the courts as described above. ${ }^{213}$

Even if the courts refuse to look at these interpretive sources, article 55 provides by its own terms a rule of law on discrimination that should meet the domestic requirements of precision. It is far more specific, for instance, than the equal protection clause of the United States Constitution. .14 $^{21}$

For these various reasons, it is difficult to follow the reasoning of the California Supreme Court in Fujii. ${ }^{215}$ Admittedly, much of the "language used in articles 55 and 56 is not the type customarily employed in treaties which have been held to be self-executing."216 The court failed, however, to observe that other American courts have applied less dcfinite and less detailed treaty provisions than those the court chooses to cite. Similarly, it did not mention that many Ameri-

208. U.N. ChARTER, art. 1, para. 3; art. 13, para. 1; art. 76(c); see note 1, supra.

209. Schachter, supra note 24 , at 651 .

210. See Part IIIB infra.

211. See, e.g., the Convention on the Elimination of All Forms of Racial Discrimiination (in force since 1969); M. GANJI, supra note 63, at 130 \& n.55. For discrimination against aliens see, e.g., Doehring, Non-Discrimination and Equal Treatment under the European Human Rights Convention and the West German Constitution with Particular Reference to Discrimination against Aliens, 18 AM. J. CoMP. L. 305, 310-17 (1970).

212. Ganji found 68 constitutions reflecting this principle. M. GANJI, supra note 63 , at 131 .

213. Umiversal Declaration, art. 2; Covenant on Civil and Political Rights art. 2; Covenant on Economic, Social and Cultural Rights art. 2. See text accompanying notes 206-08 supra.

214. U.S. CoNST. amend. XIV, § 1 provides that no state shall "deny to any person within its jurisdiction the equal protection of the laws."

215. Fujii v. California, 38 Cal. 2d 718, 242 P.2d 617 (1952).

216. Id. at $723,242 \mathrm{P} .2 \mathrm{~d}$ at 621 . 
can courts, mcluding the United States Supreme Court, have repeatedly endorsed the interpretive principle according to which treaties protecting individual rights should be liberally construed.217 Moreover, the Fujii court failed to consider the international legal context in order to render the human rights clauses more specific. Finally, the court seems to have taken the "all or nothing" approach to the human rights provisions of the Cliarter, ${ }^{218}$ rather than recognizing that the nondiscrimination element in article 55 is a self-sustaining and definite rule of law even if other human rights are not specified clearly enough to be protected on the basis of the Charter provisions.

The court's conclusion did not gain much strength from its reference to articles 104 and 105 of the Charter, which confer "legal capacities" and "privileges and immunities" upon the organization to the extent "necessary for the exercise of its functions and the fulfillment of its purposes." In view of the variety of legal capacities, privileges, and immunities specified in international conventions, ${ }^{210}$ it is difficult to see wliy the Fujii court found this language "clear and defmite" in contrast with the language of the nondiscrimination rule in article 55.220 Further, even if the court considered the Charter's concept of international human rights as too broad, it miglit still have construed this term as at least a reference to the body of basic rights protected under the United States Constitution. Thus construed, the clauses would, at a minimum, prohibit discriminatory protection of those constitutional rights. Presumably, the Court did not adopt this version because the equal protection clause provided an adequate basis for helping the plaintiff without reliance on the "remote and novel authority of the Charter."221

217. See Schachter, supra note 24 , at $657 \&$ n.72. For more details see Wright, supra note 4, at 75-78.

218. See text accompanying note 207 supra.

219. For descriptions see, e.g., C. JENKS, International IMMUNITIES (1961);

G. Weissberg, The INTERnational Status of the United Nations (1961).

220. See 38 Cal. 2d 718, 722-24, 242 P.2d 617, 620-22 (1952).

221. Fairman, Finis to Fujii, 46 AM. J. INT'L L. 682, 689 (1952).

Because the status of sex discrimination under the equal protection clause of the United States Constitution is still somewhat uncertain, American courts dealing with allegations of such discrimination would have more reason to refer to the charter provisions. Recourse to these provisions would be strengthened by noting that in the preamble, the "peoples of the United Nations" reaffirm "faith in . . . the equal rights for men and woinen." See also Convention on the Political Rights of Women, in force since July 7, 1954, 193 U.N.T.S. 135.

Interestingly enough, Wilson v. Hacker, a decision concerning the exclusion of women froin bartending, referred to arts. 2 and 23 of the Universal Declaration as "[i]ndicative of the spirit of our times." 200 Misc. 124, 135, 101 N.Y.S.2d 461, 473 (Sup. Ct. 1950).

Courts accepting the Charter provisions as relevant to a claim of sex discrimiuation would still have considerable latitude in determining whether a given regulation actually discriminates against women-that is, whether the different treatment is ra- 
In sum, the nondiscrimination rule in articles 55 and 56 may be said to have the greatest chance to meet the various precision standards of the national legal orders, and thus the greatest chance to be applied directly by national courts. ${ }^{222}$ It may even be construed to prohibit the enforcement of restrictive, discriminating agreements between private parties. ${ }^{223}$ Moreover, any active persecution of persons on account of their race, language, or religion would be clearly inconsistent with this Charter principle. ${ }^{24}$ While this rule certainly contains international obligations, it has mandatory effect upon public authorities includimg the courts only in so far as the Charter is accepted as superseding conflicting national law. ${ }^{225}$

One other aspect of precision needs discussion. As mentioned earlier ${ }^{226}$ the precision of a treaty provision is considered a crucial indicator of the parties' intent to create justiciable norms. While the intent doctrine should be abandoned in any case because of its inconsistencies, ${ }^{227}$ its present use by many courts may lead them to deny the self-executing nature of the clauses. An admissible though not very progressive argument is that the absence of the relevant intent should be presumed when the breadth of the concepts involved requires recourse to other international rules. This would amount, however, to an exclusion, for the sake of a merely fictitious intent, of the international legal context as a guide to interpretation. One inay doubt whether this dogmatic provincialism is an appropriate attitude toward today's international liuman rights law.

\section{Creation of Subjective Rights}

The concept of individual subjective riglits appears throughout the discussions of self-executing treaties. In Fujii, the California Su-

tional or justified in particular circumstances. Lauterpacht advocates a cautious approach to this question:

Thus, although a reasonable interpretation of the Charter does not require that Members of the United Nations should henceforth with one stroke grant full equahity to women in all respects, a State would no doubt act contrary to its obligations under the Charter if, under the impact of an anti-feminist regime, it were drastically to curtail the existing rights of women.

H. LAUTERPACHT, supra note 27 , at 153 . Twenty-two years after this statement, one might feel that even in the absence of an anti-feminist regime or drastic curtailments of women's rights, the courts should be bound under the Charter to subject any statutory sex discrimination to stringent scrutiny.

222. But cf. Camacho v. Rogers, 199 F. Supp. 155, 158, 32 I.L.R. 368, 369 (S.D.N.Y. 1961). The court rejected the argument that art. 55 prohibits a denial of the vote on the basis of ilhteracy in English, holding that art. 55 is not self-executing.

223. Scliacter, supra note 24 , at $656 \&$ n.67. For more details see text accompanying notes 241-43 and IIIA(2) infra.

224. H. LAUTERPACHT, supra note 27 , at 153.

225. See the discussion of this issue under IIIB infra.

226. See text accompanying notes 108,115 supra.

227. See text accompanying notes 106-11, 117 supra. 
preme Court relied on the absence of provisions that "purport to . . . create rights in private persons," of "rules governing rights and obligations of individuals," and finally of an "intent to create justiciable rights in private persons." ${ }^{228}$ Pauling $v$. McElroy loolds that the human riglits clauses do "not vest plaintiffs with individual legal rights which they may assert in the Court."229 Likewise, American authors emphasize that a treaty must create rights and duties in individuals in order to be self-executing. ${ }^{230}$ Moreover, numerous courts and legal writers in Europe require that the treaty create or affect individual rights and duties. ${ }^{231}$

An analysis of these statements reveals that they are concerned not only with the substantive status of individual rights but also with the procedural matter of their capacity to be vindicated in courts-that is, questions of remedy and standing. ${ }^{232}$ Thus, in the leading decision of the German Reichsgericht, the court said that "[A]n individual is entitled to advance claims under its [the Treaty of Versailles] provisions only in so far as this can be determined with complete clarity froin the treaty itself." ${ }^{233}$

Nevertheless in many instances, particularly in the United States, statements that a treaty does not create individual rights apparently do not describe the prerequisites for internal application but rather are merely another way of expressing the conclusion that the treaty provision is not a rule of law binding upon the courts. The discussion of individual rights appears to serve exactly this function in the reasoning of both Fujii and Pauling v. McElroy.

The separate civil law doctrines of subjective rights appear, however, to have sonie impact on the European theories of self-executing treaties. The criteria determining the existence of subjective rights are very similar to the prerequisites for the applicability. According to the German doctrine, for instance, the operative rule of law nust be mandatory; it must describe precisely the regulated behavior of individuals and certain state organs; and it must be designed to serve the interests of individuals. In addition, the individual must be allowed to enforce the rule through the courts. ${ }^{234}$ Except for the last, these criteria have

228. 38 Cal. 2d 718, 722-24, 242 P.2d 617, 620-22 (1952).

229. 164 F. Supp. 390,393 (D.D.C. 1958), aff'd 278 F.2d 252, cert. denied 364 U.S. 835 (1960).

230. E.g., Riesenfeld, supra note 19 , at 550 .

231. For details and numerous references see A. BLEckManN, supra note 2, at 17-41, 158-59; A. KOLLER, supra note 2, at 76-79.

232. These are analyzed in A. BLECKMANN, supra note 2, at 174; A. KolleR, supra note 2 , at 79 .

233. Judgment of Mar. 29, 1928, 121 RGZ 7, 9 (emphasis added).

234. For an interesting analysis of the relationship between the doctrine of sub- 
already been discussed in the present study. As far as the procedural criterion is concerned, it may suffice to note that, generally, legal norms must be applied or observed by public authorities whether or not the individual can invoke the rule before the courts.

Accordingly, the doctrine requiring subjective rights cannot be said to itself make the human rights clauses non-self-executing. Hence, in so far as the clauses meet the above tests and are therefore self-executing, they are binding upon administrative agencies and courts. In practice, self-execution provides a strong presumption that individuals can invoke treaty clauses in the courts. The final decision in this regard is left, however, to the procedural law of the forum state, unless one accepts a superseding procedural human right to effective enforcement procedures for substantive human rights. ${ }^{235}$

Three aspects of the problein of the self-executing nature of the human rights provisions may serve to illustrate that the question of selfexecution is separate froin that of whether subjective rights have been created. The nondiscrimination rule in article 55 might be said not to itself create subjective rights. It can nevertheless be binding upon public authorities and may even be invocable by individuals before the courts if the discriminatory state behavior affects private interests that are protected as subjective rights; the existence of these rights provides a legal basis for a remedy-that is, standing (Klagebefugnis).

On the other hand, social and economic rights will probably not be considered subjective rights because the Charter, even as construed above, lacks the necessary precision with regard to the regulated state behavior. Consequently, individuals will probably not be entitled to standing to advance those claims. But this does not preclude public authorities from, for example, considering some of these rights as mandatory guiding principles for the legislature or looking at them while construmg pertinent domestic laws.

Finally, in the context of infringements upon fundamental freedoms in administrative procedures or criminal law enforceinent, many states provide remedies without requiring that a subjective right be created by the violated rule of law. Accordingly, the character of the pertinent human rights as objective rules of law would be a sufficient basis for direct application in this procedural context.

jective rights and the doctrine of self-executing treaties see A. BLECKMANN, supra note 2, at 92-103. Cf. A. Koller, supra note 2, at 76-79.

235. Such as provided for in European Conveution on Human Rights art. 13: "Everyone whose rights and freedoms as set forth in this Convention are violated shall have an effective reinedy before a national authority ...." Art. 2, $\$ 3$ of the Covenant on Civil and Pohtical Rights is to similar effect. But see art. 8 of the Universal Declaration. 


\section{III}

\section{The Application of the Clauses}

Whereas the second part of this paper was primarily concerned with the prerequisites for direct application of the human rights clauses, this part will summarize the various forms of application and their possible internal effects. This survey is partly based on the foregoing analysis, from which it will draw some conclusions and generalizations.

\section{A. Forms of Application}

The domestic status notion refers to a fairly broad range of forms of application. Thus, certain parts of the human rights clauses may bind the legislature exclusively, while others may be applied by the executive branch. Our major concern here is the application of the clauses by the courts, either ex officio or upon request by individuals. This judicial application can take very different forms, as the previous analysis indicates.

\section{Direct Application}

The most important form of judicial application is direct application-judicial reliance on the governing rule of law as the primary basis for the logical process underlying the case decision. Exactly this function may be performed by the human rights clauses to the extent that they ineet the various requirements considered above.

I have distinguished two inajor forms of direct application that involve differentially strimgent self-executing requirements. ${ }^{230}$ In the first form, the clauses serve as a standard against which the courts may ineasure the legality of state behavior affecting individuals. Wherever the courts are competent to review acts of public authorities, they may have to strike down those acts that infringe upon the fundamental freedoms protected by the Charter. This may require injunctions against public authorities at all levels, federal as well as state, ${ }^{237}$ reversals of lower judgments, nullification of administrative and even legislative acts, and similar judicial controls of state behavior. ${ }^{238}$

Parenthetically, it may be noted that the procedural forms are, of course, provided by the domestic law. This determines and, in some instances, limits the internal significance of the human rights clauses.

236. Cf. A. BleCKMANN, supra note 2, at 74; A. Koller, supra note 2, at 107.

237. See H. LAUTERPACHT, supra note 27 , at 158 .

238. Cf. Wright, supra note 4, at 77-78. Administrative courts in Europe have consistently reviewed administrative acts such as expropriations and expulsions under international treaties. See A. BLECKMANN, supra note 2, at 74. For cases governed by the European Convention on Human Rights see, e.g., Buergenthal, supra note 13. 
Thus, the procedural law may subject judicial control of state behavior to certain conditions, such as standing requirements or waivers of state immunity. It may also bar individuals from invoking fundamental rights other than doinestic ones before certain branches of the judiciary. ${ }^{230}$

To be sure, certam social and economic rights may in primciple also function to control governmental behavior, particularly in cases involving discrimination. It is doubtful, however, whether they inay also serve as a basis for enforcing governmental obligations to perform - for example, to provide for social security, favorable conditions of work, protection agamst unemployment, adequate education, and the like. These rights, while they inay be inandatory principles for legislative guidance, can rarely be vimdicated by individuals; they do not define the prescribed state behavior precisely enough. ${ }^{240}$

The human rights clauses may even provide a device for judicial control of social and economic discrimination by private orgamizations and institutions. Those bodies can be controlled in the United States under the concept of state action in many cases in which the assistance or resources of the state are sought or used for purposes inimical to those fundamental objectives of the Charter. ${ }^{241}$ In Europe, similar approaches have been advocated. ${ }^{242}$ The prevailing tendency in the context of relationships among private parties, however, seems to be the application of fundamental rights merely as a standard for the interpretation of general clauses in private law, such as ordre public, Treu und Glauben, and Sittenwidrigkeit (unconscionability). ${ }^{243}$

\section{Indirect Application}

The interpretive function exercised by the human rights clauses in the process of judicial decision inaking can be characterized as indirect application. The clauses may guide the courts in the specification of domestic rules of law governing, among other things, contractual and tort relationships between private parties. Hence, certain contracts which discrimmate on proscribed grounds among individuals

239. See text accompanying note 12 supra.

240. See text accompanying notes 186-89 supra. See generally A. Bleckmann, supra note 2, at 74, 76-77; A. KoLLER, supra note 2, at 107.

241. Lauterpacht already felt similarly in 1950. H. LAUTERPACHT, supra note 27, at 155. Cf., e.g., Lewis, The Meaning of State Action, 60 Colum. L. Rev. 1083 (1960).

242. E.g., the theory of Drittwirkung der Grundrechte (Third Party Effects of Fundamental Rights) in West Germany.

243. E.g., BGB $\$ \$ 134,242,826$. See also Doehring, supra note 211, at 317, referring to the situation under both the German Constitution and the European Convention on Human Rights. 
may be declared void and unenforceable, and certain forms of discriminating behavior may lead to tort liability.

The courts in the United States and other common law countries may refuse to enforce private contractual rights by holding that the agreement conflicts with the state's public policy-for exanple, its pledge of nondiscrimination. ${ }^{244}$ Thus, in Re Drummond Wren, the High Court of Ontario, Canada, refused to enforce a restrictive covenant based on ethnic discrimination, finding it offensive to the public policy of Canada. In determining this policy, the court invoked, inter alia, the preamble and articles 1 and 55 of the Charter. ${ }^{245}$

American courts have considered some international treaties ingredients of United States public policy. ${ }^{248}$ No court opinion has as yet, however, imvoked the human rights clauses when refusing to enforce discriminating private agreenients. ${ }^{247}$ Moreover, some courts have exphicitly rejected this approach when urged upon them in the briefs. In Sipes v. McGhee, for example, the Michigan Supreme Court said, "We do not understand it to be a principle of law that a treaty between sovereign nations is applicable to the contractual rights between citizens of the United States when a determination of these rights is sought in State courts."248 The human rights clauses, the court held, are "merely indicative of a desirable social trend and an objective devoutly to be desired by all well-thinking people," ${ }^{240}$ rather than constituting an applicable legal principle. Sinilarly, the Supreine

244. See H. LAUTERPACHT, supra note 27, at 156-57; Schachter, supra note 24, at 656-58; cf. Fairman, supra note 221, at 689; P. JESSUP, supra note 51 , at 89 . See also REPORT, supra note 92, at 4.

245. [1943-45] Ann. Dig. 178, 179 (No. 50) (High Court, Ontario, Can. 1945). For comments on this decision see, e.g., H. LAUTERPACHT, supra note 27, at 155-56 and n.23; L. OPPENHEIM, supra note 14, at 741 n.4; Sayre, United Nations Law, 25 CaN. BAR Rev. 809, 815 n.5, 821 et seq. (1947); Sayre, Shelly v. Kraemer and United Nations Law, 34 Iowa L. Rev. 1, 2, 8 (1948); Schachter, supra note 24, at 657 n.70. See also text accompanying notes 259-60 infra.

246. See, e.g., Hurd v. Hodge, 334 U.S. 24, 34-35, [1947] Ann. Dig. 99 (No. 36) (1948): "The power of the federal courts to enforce the terms of private agreements is at all times exercised subject to the restrictions and limitations of the public policy of the United States as manifested in the Constitution, treaties, federal statutes, and applicable legal precedents. Where the enforcement of private agreements would be violative of that policy, it is the obligation of courts to refrain fronl such exertions of judicial power." (Emphasis added.)

247. But see the short references to the Universal Declaration in Wilson $v$. Hacker, 200 Misc. 124, 135, 101 N.Y.S.2d 461, 473 (Sup. Ct. 1950), and the citation of art. 20 of the Declaration (freedom of association) in J. Frankfurter's concurring opimion in Lincoln Federal Labor Union v. Northwestern Iron \& Metal Co., 335 U.S. 525 (1948), and American Federation of Labor v. American Sash \& Door Co., 335 U.S. 538,549 n.5 (1949).

248. 316 Mich. 614, 628, 25 N.W.2d 638, 644, [1947] Ann. Dig. 96 (No. 35) (1947).

249. Id. 
Court of New York contended in Kemp v. Rubin that "[t]hese treaties have nothing to do with domestic matters nor with agreements between citizens of the United States." ${ }^{250}$ Finally, in Rice v. Sioux City Memorial Park Cemetery, the Supreme Court of Iowa, relying on Sipes and Fujii, held that the Charter "has no application to the private conduct of individual citizens of the United States," and thus implied that it does not limit the constitutional rights of the states and of private persons. ${ }^{251}$

The reasoning of these state courts is difficult to follow. They appear to reject a public policy approach on the sole ground that the human rights clauses, although part of an international treaty, are not self-executing or even mandatory. In the hight of the preceding analysis, this position is questionable. Indeed, there is significant support for the opposite conclusion - that the Charter's nondiscrimination rule, the relevant rule in the context of restrictive covenants, is self-executing under United States constitutional law; ${ }^{252}$ if so, it must be a part of the public policy of the United States.

Even if the human rights clauses were not self-executing, however, the United States' legally bimding human rights commitınent in article 56 would still have to be considered as indicative of public policy. ${ }^{253}$ Judge Edgerton of the United States Court of Appeals for the District of Columbia was right, therefore, when he wrote in his dissenting opimion in Hurd $v$. Hodge that the United States' pledge in article 56 "cannot be neglected in any consideration of the policy of preventing inen froin buying homes because they are Negroes."

This leads to a significant feature of the Charter's internal effects: The human rights clauses may have some impact upon the judicial determination of public policy even if their self-executing nature is denied under the relevant tests. In other words, even where the clauses are merely considered as a program binding only upon the legislature, they may bar the courts from enforcing private agreements that are offensive to the public policy derived froin the Charter. ${ }^{255}$ Thus, social

250. 188 Misc. 310, 315-16, 69 N.Y.S.2d 680, 686, [1947] Ann. Dig. 100 (No. 37) (Sup. Ct. 1947), aff'd 75 N.Y.S.2d 768, rev'd and complaint dismissed mem. 298 N.Y. 590 (1948).

251. 245 Iowa 147, 157-58, 60 N.W.2d 110, 116-17 (1953), aff'd, 348 U.S. 880, vacated on rehearing and cert. dismissed, 349 U.S. 70 (1955). On rehearing, the United States Supreme Court noted that its earlier divided opinion did not reflect a division of the Court on the question of the effect of the Charter on private people. 349 U.S. at 73.

252. Schachter, supra note 24 , at 651 .

253. Id. at 655 .

254. 162 F.2d 233, 245, [1947] Ann. Dig. 98 (No. 36) (D.C. Cir. 1947), rev'd, 334 U.S. 24 (1948).

255. But cf. cases cited notes 247-51 supra. See A. BLeCKMANn, supra note 2, at $72 \mathrm{n} .71$ with references to the law in West Germany and the Netherlands. 
and economic rights may have some indirect effect upon contractual rights of private parties even though they are not enforceable against the government. For example, the principle of just and favorable conditions of work, ${ }^{258}$ since it indicates the member states' policy, should convince the courts not to enforce against workers labor contracts that blatantly violate this principle. ${ }^{257}$ Hence, it is the indirect application of the human rights clauses which could have considerable effect upon the social and economic situation in many countries.

In countries that do not accept the Charter as the law of the land, however, even such indirect application is difficult. The High Court of Ontario, Canada, for example, has departed from the position previously taken ${ }^{258}$ and refused to rely on the Charter in the absence of any Canadian legislation giving effect to the potential Charter obligations. ${ }^{250}$ On appeal, the Ontario Court of Appeal reaffirmed this reasoning, stating that no reference may be made to principles and obligations set forth in international covenants and charters "until such time as they should be made a part of the law of the land."200

Likewise, a British authority, while recognizing the potential impact of international treaties even if not incorporated in English public policy, concludes that the human rights clauses cannot by themselves affect public policy unless they are considered as evidence for a rule of customary international law to which English public policy might give effect. ${ }^{281}$ Moreover, he intimates that the Charter's nondiscrimination principle may not restrict the freedom of contract, which is itself a principle of public policy, since the Charter is not part of the law of the land. ${ }^{262}$ Fourteen years after this statement, however, the Charter might be given inore weight in the context of judicial determination of English public policy as evidence of the growing body of customary human rights law. ${ }^{203}$

In this connection, it is interesting to note a decision of the High Court of Orissa, India, ${ }^{284}$ affirming an expropriation under the Orissa

256. See the text of art. 23 of the Universal Declaration and art. 7 of the Covenant on Social, Economic and Cultural Rights.

257. See also note 247 supra.

258. [1943-45] Ann. Dig. 178, 179 (No. 50) (High Court, Ontario, Can. 1945). See text accompanying note 245 supra.

259. Re Noble and Wolf, [1948] Ann. Dig. 302, 305 (No. 100) (High Court, Ontario, Can. 1948).

260. [1948] Ann. Dig. 306, 308 (No. 100) (High Court, Ontario, Can. 1948).

261. Mann, The Enforcement of Treaties by English Courts, 44 Grotius Soc'y 29, 43-46 (1958-59).

262. Id. at 47 .

263. See generally D. O'ConNelL, supra note 14, at 56-58; I. BROWNLIE, supra note 77 , at 38-43.

264. Biswambhar Singh v. State of Orissa, 24 I.L.R. 425 (High Court, Orissa, India 1957). 
Estates Abolition Act of 1952. While recognizing that the human right to private property as expressed in article 17 of the Universal Declaration may be embodied in the Charter, the court refused to accept a corresponding public policy in view of the contrary policy authoritatively expressed in article 31 of the Indian Constitution, which renders coinpensation disputes nonjusticiable. ${ }^{265}$ The decision indicates that there are certain limitations to the internal effect of the human rights clauses; these limitations will be discussed below.

Froin the viewpoint of legal technique, the determination of public policy inay becoine nothing more than the interpretation of codified public policy clauses. ${ }^{208}$ In this process, as well as in the interpretation of other domestic laws, the human rights clauses inay play a role. There is ample authority supporting the argument that courts inay look at international treaties as guidance for the interpretation of doinestic law, and that domestic law should be construed to avoid conflicts with international treaties. ${ }^{207}$ Consequently, an interpretive function inust be ascribed to the human rights clauses of the Charter.

A number of American authorities have actually taken this position. The 18th Report of the Commission to Study the Organization of Peace, for example, states that the clauses, even if not self-executing, "can assist in inore hiberal interpretation of constitutional and legislative provisions, thus enlarging the sphere of the domestic protection of human rights." ${ }^{268}$ Likewise, Schachter expects that the clauses will be a factor in resolving constitutional issues and that they "will be cited as an added reason for extending constitutional liberties." 269 More specifically, one author submits that the Charter may be utilized to give a fuller and more liberal content to the constitutional definition of equality under the equal protection clause. ${ }^{270}$

Although the human rights clauses may serve as guidelines in the interpretation of constitutional and legislative provisions regarding huinan rights and fundamental freedoins, the significance of this inter-

265. Id. at 426-27. At the same time, the court recognized that the Declaration may be invoked in certain cases on grounds of public policy. Id. at 426.

266. This is the case particularly in the civil law countries (e.g., ordre public).

267. See A. BLECKMANN, supra note 2 , at 75 , with a thorough analysis at $85-92$, and numerous references to European authorities at 85 n.114; cf. McLaughlin, supra note 99 , at $751 \&$ n.148 (references to American decisions).

268. REPORT, supra note 92, at 4.

Since lawyers are widely reluctant to confess that the values established by the national constitutions fall below any requirement of the Charter, they will rarely explicitly rely on the Charter. This reluctance may eventually lead the courts to more liberal interpretation of the basic rights and freedoms embodied in the constitutions. Fairman, supra note 221, at 689; see Schachter, supra note 24, at 658; cf. Partsch, Internationale Menschenrechte, 74 ARCHIV DES öFFENLICHEN RECHTS 158, 180 (1948).

269. Schachter, supra note 24 , at 658 (emphasis added, footnote omitted).

270. Comment, U.N. Charter, supra note 63, at 809. See also note 221 supra. 
pretive function should not be over-estimated. The clauses themselves need extensive interpretation because of their breadth. It may be expected that the courts will prefer to seek interpretive guidance in international custoinary law and general principles, as fornulated in the International Bill of Human Rights, rather than in the Charter itself. This has been the tendency in the past. While the few American decisions referring to the Universal Declaration do so inerely to identify public policy, ${ }^{271}$ a number of foreigu courts have invoked specific provisions of the Declaration as evidence of generally accepted principles of international law. ${ }^{272}$ Other courts, in interpreting constitutional and other domestic provisions, have attached varying importance to the Universal Declaration. ${ }^{273}$

271. See cases cited note 247 supra. Cf. Schwelb, supra note 6, at 226. But see Kennedy v. Mendoza-Martinez, 372 U.S. 144, 161 n.16 (1963), mentioning art. 15 of the Universal Declaration in the context of a discussion of the 14th amendment.

272. Auditeur Militaire c. Krumkamp, Pasicrisie Belge (Feb. 8, 1950), (Conseil de Guerre de Brabant, Belgium 1950) in 46 AM. J. INT'L L. 162 (1952) (accepting the Declaration, in particular art. 5 (cruel, inhuman or degrading treatment or punishment) as guidance "in looking for principles of international law which result from the usages established among civilized peoples"); Judgment of Nov. 27, 1964, [1965] Foro Ital. II. 122, 126 (Corte d'appello di Milano) (characterizing art. 14 (asylum) as norme del diritto internazionale generalmente riconosciute internally binding by virtue of art. 10 of the Itahan Constitution); Ministry of Home Affairs v. Kemali, 40 I.L.R. 191, 195 (Corte di Cassazione, Italy 1962) (recognizing art. 15 (nationality) as a "principle common to the law of every nodern state" that has become internal law by virtue of art. 10 of the Italian Constitution and by virtue of the act incorporating the European Convention on Human Rights); Re Krüger, [1951] Ann. Dig. 258, 259 (Council for the Restoration of Legal Rights, Neth. 1951) (citing art. 15, para. 3 (nationality) to support the assertion that no state may deprive resident aliens of their citizenship); Borovsky v. Commissioner of Immigation, 90 Philippine Reports 107, [1951] Y.B. Human Rights 287-88 (Supreme Court, Philippines 1951) (relying, in a case concerning the indefinite keeping of an atien in detention without formal criminal charges, on arts. 1, 2 (nondiscrimination), 8 (effective remedy), and 9 (arbitrary detention) as generally accepted principles of international law as adopted by art. $2, \S 3$ of the Philippine Constitution).

But see The State (Duggan) v. Tapley, [1951] Ann. Dig. 336, 342 (No. 109) (Supreine Court, Eire 1950), denying that art. 14 is a statement of the existing law of nations and insisting that it is "not a guide to discover the existing principles of international law." See also In re Beck, [1949] Ann. Dig. 279, 280 (No. 93) (Special Court of Cassation, Neth. 1949), doubting whether art. 11, para. 2 (nullum crimen sine lege) is a fornulation of a general principle of law recognized by civilized nations.

273. See the significant Judgment of July 12, 1955, 22 I.L.R. 520, 524 (Bundesgerichtshof, W. Ger.). The court, while interpreting the Gernan Extradition Law, referred to art. 14 of the Declaration "which the Federal Constitution seeks, generally speaking, to follow."

In Judginent of March 20, 1954, [1954] Giur. Ital. II 573, 581 (Tribunale Taranto), the court, while denying that art. 15 has the force of a binding rule of law, characterized it as a direttiva di massimo di alto valore morale indicating the state's policy in the area of nationality.

In re Flesche, [1949] Ann. Dig. 266, 269 (No. 87) (Special Court of Cassation, Neth. 1949), the court denies that the Declaration contains any "indication . . . of a general legal opimion which places the principle of 'specialty' among fundamental 
Yet, while very few judicial statements rely directly on the human rights clauses of the Charter as guidance for the construction of constitutional provisions, the considerable potential impact of the clauses upon the development of constitutional law by judicial interpretation is demonstrated by the decision of the Supreme Court of Oregon in Namba v. McCourt. ${ }^{274}$ Here, the court construed the equal protection clause as prohibiting alien land laws that discriminate on the basis of race, color or creed. In reaching this conclusion, the court rehed, inter alia, on the binding principle of nondiscrimination in articles 55 and $56 .^{275}$

At the present time, however, many courts still seem hesitant to acknowledge the interpretive role of international law generally. This is particularly true in cases involving interpretation of legislation that was not enacted in order to meet the Charter obligations. In this instance, courts will regard international treaties as an aid to interpretation of domestic law only if they accept the objective of achieving conformity between national and international law. When the constitution or the statute concerned contain any reference to the Charter, and particularly to the human rights clauses, either expressly or by inference froin legislative history, however, literal, historical, and subjective methods of interpretation compel the courts to consider the impact of the human rights clauses; ${ }^{276}$ adoption of the language of the Declaration in national constitutions may be interpreted as a reference to obligations under article 56 of the Charter. ${ }^{277}$

This interpretive approach does not require that the human rights

rights of man."

In re Car, 39 I.L.R. 460, 461 (Conseil d'Etat, France 1960), the Conseil held that the mere fact of the publication of the Declaration in the Journal Officiel does not justify considering it a treaty having force of law under the French Constitution. The opposite view was expressed in 1959 by the Paris Court of Appeals in Sté Roy Export et Charbe Chaplin c. Soc. Le Filın Rayée Richebé, in 87 Journal du DROIT INTERNATIONAL 129, 137 (1960).

The Austrian Constitutional Court, in its Judgment of Oct. 5, 1950, as reported in 46 AM. J. INT'L L. 161 (1952), refused to apply art. 2 on the grounds that the Declaration had not been incorporated into the national law of Austria. A negative position was also taken by the Supreme Court of Ceylon in The Queen v. Liyanage, 65 New Law Reports 73, 82 (1964) (art. 11).

274. 185 Ore. 579, 204 P.2d 569 (1949). See also Oyama v. California, 332 U.S. 633 (1948) (concurring opinions); Peres v. Lippold, 32 Cal. 2d 711, 732-33, 198 P.2d 17, 29-30 (1948) (Carter, J., concurring) (considering the preamble and art. 1 of the Charter as an additional authority requiring the invalidation of a California miscegenation law).

275. 185 Ore. at 604, 204 P.2d at 579; cf. Guradze, supra note 46 , at 115.

276. For a general discussion of the conditions of interpretation in conformity with treaties see A. BLECKMANN, supra note 2, at 85-90.

277. See also Judgment of July 12, 1955, 22 I.L.R. 520 (Bundesgerichtshof, W. Ger.); for examples in recent constitutions see Schwelb, supra note 6, at 223-24 and 225 (legislative history of the French Constitution of 1958). 
clauses be considered self-executing in the particular context. Consequently, even the social and economic rights implied in the Charter may shed some light upon the content of similar constitutional or legislative provisions-for example, article 20 of the German Basic Law, defining the Federal Republic as a social federal state. ${ }^{278}$ Moreover, from a momistic poimt of view, the clauses can serve as interpretive guidance even in countries that do not accept them as the law of the land. The greater the impact of the clauses upon the content of domestic law, however, the more stringent the requirements for any internal force will be. ${ }^{279}$

\section{B. Conflicting Domestic Law}

The most extreme impact of the human rights clauses would occur if, as applied by the courts, they conflict with domestic laws that discriminate or deny fundamental freedoms. This possibility both suggests a further prerequisite to eventual application and points to an important limit on the importance of direct application.

There is general agreement that the effect of treaty provisions on conflicting domestic law is determined by the constitutional law of the parties to the treaty. ${ }^{280}$ According to a number of constitutions, treaties ratified by the state supersede any contrary municipal law. ${ }^{281}$ Most constitutions, however, rather than making treaties supreme over any municipal law, simply accept them as equivalent to domestic legislation. In such federal states as Argentina, the Federal Republic of Germany, Mexico, Switzerland, and the Umited States, treaties are equiva-

278. This very broad concept has guided German courts in cases involving social legislation. See, e.g., Decision of 16 December 1958, 9 BVerfGE 20, 35; Decision of 25 February 1960, 10 BVerfGE 354, 368; Decision of 13 December 1961, 13 BVerfGE 248, 259; Decision of 24 July 1963, 17 BVerfGE 38, 56; Decision of 26 November 1964, 18 BVerfGE 257, 267.

279. See generally A. BLECKMANN, supra note 2, at 87-88.

280. E.g., A. KoLLER, supra note 2, at 144.

281. Constitution art. 169, $\$ 3$ (Cyprus, 1962); Constitution arts. 53 and 55 (France, 1958); ConsnTumon arts. 60, 65-67 (Netherlands, 1953). The situation in Italy, Luxembourg, and Japan is probably similar. For details see D. O'ConNeLl, supra note 14 , at $70-71,77,78$.

For arts. 26-28 of the French Constitution of 1946 and the former art. 60 of the Netherlands Constitution see Evans, supra note 2, at 195, 197-98. Van Panhuys, The Netherlands Constitution and International Law, 58 AM. J. INT'L L. 88 (1964), is a study on the interesting Netherlands situation.

In West Germany, however, judieial practice and the majority of legal writers aecord subsequent federal statutes priority over a treaty. See, e.g., D. O'ConNELL, supra note 14, at 76 \& n.83. But see Evans, supra note 2, at 197, who reports the minority doctrine that art. 25 of the German Basic Law, while referring to "gencral rules of international law," secures the same rank (superior to subsequent federal statutes) to treaties by virtue of the general rule pacta sunt servanda. 
lent to federal legislation and thus supersede the laws of the component units. $^{282}$

Accordingly, the human rights clauses, to the extent they are selfexecuting, supersede any prior or subsequent non-federal legislation that conflicts with them. In relation to contrary federal legislation, however, the conflict principle that later law supersedes prior law is generally applied. A statute enacted after the acceptance of the Charter by a nation would therefore suspend the operation of the clauses, without, of course, nullifying the Charter. ${ }^{283}$

Thus, the United States District Court for the District of Columbia held in Pauling v. McElroy ${ }^{284}$ that American courts are barred from applying the human rights clauses when they conflict with a later federal statute. In this interesting case, individuals brought actions to enjom nuclear weapon tests in the Marshall Islands. The court based the dismissal on the argument, inter alia, that the Atomic Energy Act of 1954, even if it conflicted with the human rights clauses, would be paramount to those clauses because it was enacted later. ${ }^{285}$

One authority has argued that

A treaty . . . or legislative act which constitutes a gross violation of human rights ... would be clearly invalid as contrary to a basic and overriding norm of the Charter, and any tribunal, international or doinestic, which might be asked to apply such a treaty or act should refuse to do so. ${ }^{286}$

This assessnent, while correct with respect to treaties, is probably without sufficient basis as far as subsequent federal legislation in the majority of states, including the United States, is concerned. ${ }^{287}$ Those legislative acts inust be applied by the courts of those countries in preference to the human rights clauses even if they violate the international obligations under article 56. Hence, the conflict principle may considerably reduce the scope of the clauses' application and thus limit their internal effectiveness and significance.

282. See, e.g., GrundgeseTZ (Basic Law) arts. 59 and 31 (W. Ger. 1949); Constitumon art. 133 (Mexico 1917); U.S. Const. art. 6. See also D. O'ConNel, supra note 14, at 77.

283. Evans, supra note 2, at 194-205. For the situation in the U.S. see id. at 183 \& n.6; McLaughlin, supra note 99, at 751 \& n.147; Wright, supra note 92, at 4. For general discussion of the conflict principle see A. BLECKMANN, supra note 2, at 77-81.

The conflict principle does not, of course, apply in the countries mentioned note 281 supra. For the status of the Charter in French law see H. LAUTERPACHT, supra note 27 , at $158 \&$ n. 31 .

284. 164 F. Supp. 390 (D.D.C. 1958), aff'd per curiam 278 F.2d 252 (D.C. Cir. 1960), cert. denied 364 U.S. 835.

285. 164 F. Supp. at 393.

286. Sohn, Protection, supra note 92, at 325-26.

287. It is correct, of course, with respect to the states mentioned note 281 supra. 
These consequences are mitigated somewhat by the previously discussed principle that laws should be construed so as not to conflict with rules of international law. ${ }^{288}$ On the other hand, the courts do sometimes subject treaty provisions that would supersede contrary domestic law to particular scrutiny under the self-executing doctrine in order to preserve the constitutional perogatives of the legislative branch of the government, federal as well as state. ${ }^{289}$ Thus, paradoxically, the human rights clauses may sometimes be internally less effective as selfexecuting provisions than as guidelines for the interpretation of domestic law. ${ }^{290}$

\section{CONCLUSION}

While the goal of a unore comprehensive and effective protection of human rights reflects widely accepted value judgments, there is less agreement about the methods that should be employed to reach the desired results. The foregoing comparative analysis demonstrates that the domestic status of the human rights clauses is governed not by a plain, straightforward formula but rather by a complex pattern of legal theories, doctrines, and policies. Yet, despite the existence of a variety of self-executing tests, differing forms of application, and diverse national human rights systems, the human rights clauses, or at least some of their parts, are likely to have some domestic legal effect in many states. ${ }^{201}$

True, a large area of methodological controversy between momistic and dualistic views, between strict constructiomsm and judicial activism, and between supporters of national sovereignty and advocates of international law still remains; ${ }^{292}$ each of these conceptions has greatly influenced court decisions in the area of international law. Yet, whatever judicial attitudes toward international law in general may exist, they should be carefully reassessed as far as the international law of human rights is concerned. Twenty-eight years after San Francisco, it is hardly permissible to consider the Charter as a "remote and novel authority." 293 Although construction of the human rights clauses, as advocated above, clearly goes beyond the actual intent of the framers

288. See note 267 supra and accompanying text. See generally A. BlECKMANN, supra note 2, at 80; Evans, supra note 2, at 184; A. Kollar, supra note 2, at 142.

289. Cf. A. BLECKMANN, supra note 2, at 78.

290. Cf. id. at 80-81.

291. It is unlikely that Fujii v. California, 38 Cal. 2d 718, 24 P.2d 617 (1952), would be decided the same way today. Since this decision was not appealed to the U.S. Supreme Court, "the point remains unsettled for the country as a whole." Finch, The Need to Restrain the Treaty-Making Power of the United States Within Constitlltional Limits, 48 AM. J. INT'L L. 57, 72 (1954).

292. Cf. Wright, supra note 4 , at 82.

293. Fairman, supra note 221, at 689. 
of the Charter, so does the construction of the American and other constitutions in judicial practice. Moreover, the functions of the United Nations will not be frustrated as a consequence of extensive construction of the human rights clauses, nor are the states likely to hesitate to assume further commitments that may be made to serve unintended purposes. ${ }^{294}$

The survey of self-executing tests and of different forms of application reveals, not surprisingly, the close relationship between allegedly neutral legal phenomena and their social environment. The self-executing doctrines and judicial methods in Western countries strikingly reflect both the social and economic structure of the state and the position of the individual in it. While they tend to favor the internal effect of the traditional civil rights that evolved with the legal liberalism of the 19th century, they discourage any direct impact of the modern international economic and social rights. One may assume that the corresponding inethodologies and doctrines in socialist countries reflect an opposite tendency. This situation indicates not only the degree to which ideology is involved in the human rights issue, ${ }^{295}$ but also the inherent limitations of the direct application approach. The efficiency of domestic protection of international human rights largely depends, in the fimal analysis, on the flexibility and opemiess of national law and its lawyers to the liberal and social components of the concept of international human rights. It is conceivable that socially aware lawyers and judges may succeed in combining efficiency in the realization of the Charter's objectives with integrity of procedures. ${ }^{296}$

Admittedly, this legalistic approach is only one among many possible approaches to social change, others are education and political activity. The legal approach may fail in countries whose judiciary is not a relatively independent and socially innovative power, receptive to new impnlses from international law. If successful, however, this approach may have repercussions on international law by contributing to the growing bodies of general practice accepted as law and of general principles of law.

Finally, it must be borne in mind in assessing current efforts in the human rights field that existing human rights vary considerably in their actual relevance to individuals because of differences in political and socio-economic systems. In Western industrialized nations, tradi-

294. See Wright, supra note 4 , at 78-79, with a discussion of the different interpretive approaches to the Charter and the underlying policies and rationales.

295. For an interesting analysis of the cold war context of the human rights codification see Martin, Human Rights and World Politics, 1951 Y.B. WorLd AfraIRs, 37. See also the Soviet authors mentioned in note 187 supra.

296. Cf. Wright, supra note 4 , at 79 . 
[Vol. 61:110

tional civil rights now have little significance unless they protect the individual against private economic and social power. Social and economic rights, while still in a very unsatisfactory stage of developinent in these countries have becoine inore and more important. In the areas of civil as well as social and economic rights, both the present international law of human rights including the Charter and national legal techniques such as the concept of "domestic application" may provide some legal tools, albeit unsatisfactory, for social progress through the judiciary. 